\title{
Study of Climate Change in Niger River Basin, West Africa: Reality Not a Myth
}

\author{
Juddy N. Okpara, Aondover A.Tarhule and Muthiah Perumal
}

Additional information is available at the end of the chapter

http://dx.doi.org/10.5772/55186

\section{Introduction}

Before the beginning of $21^{\text {st }}$, when the subject of global warming and climate change became a frontline issue among the climate scientists, it was thought by a lot of people, especially the decision- and policy-makers that climate change was a myth and not real. This underscores the reason why many countries even till today are not convinced yet why they should ratify the Kyoto protocol. But today, hardly is there any part of the globe that has not experienced the impacts of climate change either positively or negatively. As a result, addressing climate change issue has become one of the humanity's most pressing and difficult environmental challenges of our time, requiring urgent and concerted efforts. It is a complex, long-term problem, two centuries in the making. Climate change is ubiquitousthere are only, but a few human activities that do not contribute to it. Its effects are already being felt all over through weather and hydrological extremes (floods and droughts) in the Niger River basin and will only worsen, seriously affecting in particular sustainable development, with adverse impacts on the economic development of developing countries, as well as social welfare, the environment, natural resources and physical infrastructure. It would certainly most likely affect in general, the way of life in all countries, especially the developing countries with low resilience(depending on river basin's resources), as well as fragile ecosystems and even threaten global security through migratory pressures and resources conflicts. Again, the existing mismatch between the primary culprits of climate change and the primary victims of its impacts often bedeviled international efforts to address the problems at global level; and there is no other place this climatic impact is more obvious and critical than in countries of Africa, particularly the West African region; even though they have contributed just a little or nothing to the factors responsible for the global warming. Even though, there is no consensus amongst the Global Climate Models (GCMs) over the future climate of the West Africa [1], the region's experience so far, starkly demonstrates the development setbacks and high level of vulnerability of the area to 
impacts of climate change; ranging from recurrent droughts, Niger River zero flow of 1984 and 1985 at Malaville and Niamey (Benin and Niger) respectively, to shrinkage and disappearance of Lake Chad, devastation of Abuja National stadium velodrome, collapse of connecting Nukkai and Sokoto bridges, in 2003, 2005 and 2010 respectively (all in Nigeria). This is because; the current climate of the region is strongly characterized by climatic variability and extreme events (floods and droughts) that already have serious implications on economic development of the region.

It is now very obvious too that an inherent characteristic of climate is change, and a period of change is already underway which has the potential to threaten the fabric of human society and its development across the globe both at present and in the future. This is because climate, development and the world's water-resource systems of a river basin have a unique relationship insofar as water resources depend on the hydrological cycle which is itself part of the Earth climate system driven by the sun's energy. What came to be known as global warming (i.e. the rising of average air temperature of the Earth's atmosphere and ocean) that began to increase in the late 19th century (Fig. 1) and is projected to continue rising is human's making; through human's deliberate actions to conquer nature, as against living in harmony with natural systems. Global warming is the main culprit of climate change. While humans have affected weather and climate, weather and climate have in turn affected humans through extreme events (Fig. 2).As a result, there has been growing needs to study, understand and quantify the potential impacts of climate change on climate sensitive sectors of national economies and the hydrologic regimes. Also, decision-makers in many climate-sensitive sectors: water, energy, agriculture, fisheries, health, forestry, transport, tourism, disaster risk management - are now more than ever before, increasingly concerned by the growing adverse impacts of climate change associated risks, because they are ill-equipped to adequately tackle these challenges.

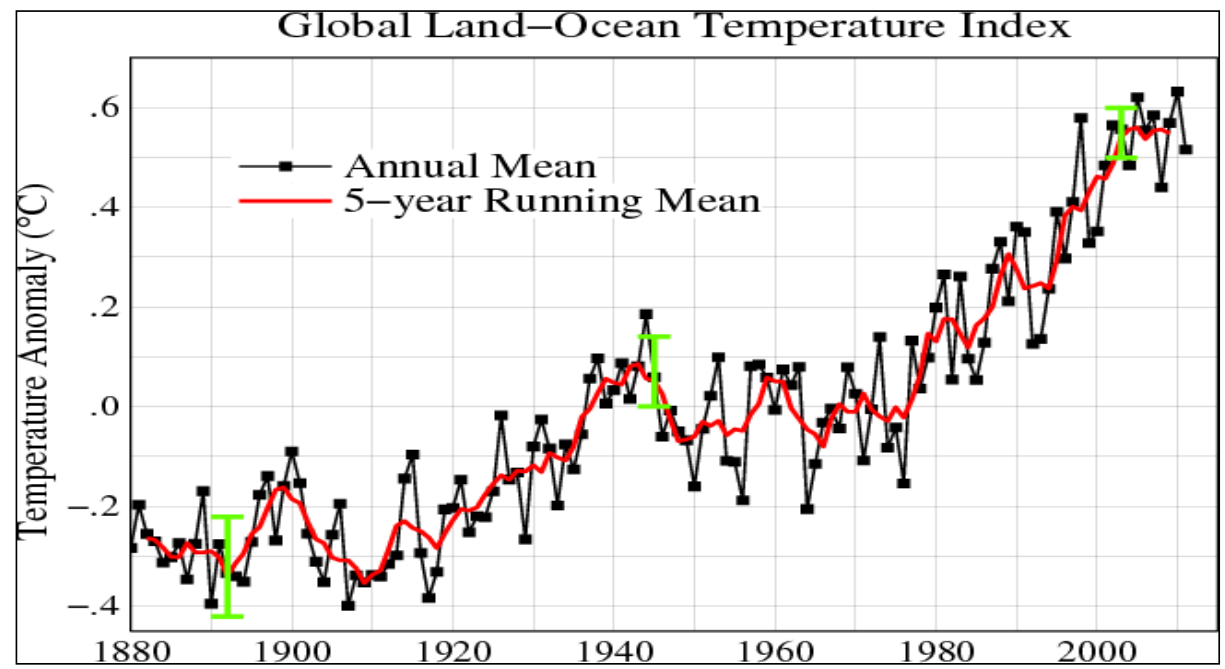

Figure 1. Global Temperature Anomaly 1880-2010 (Sources NASA, 2011) 


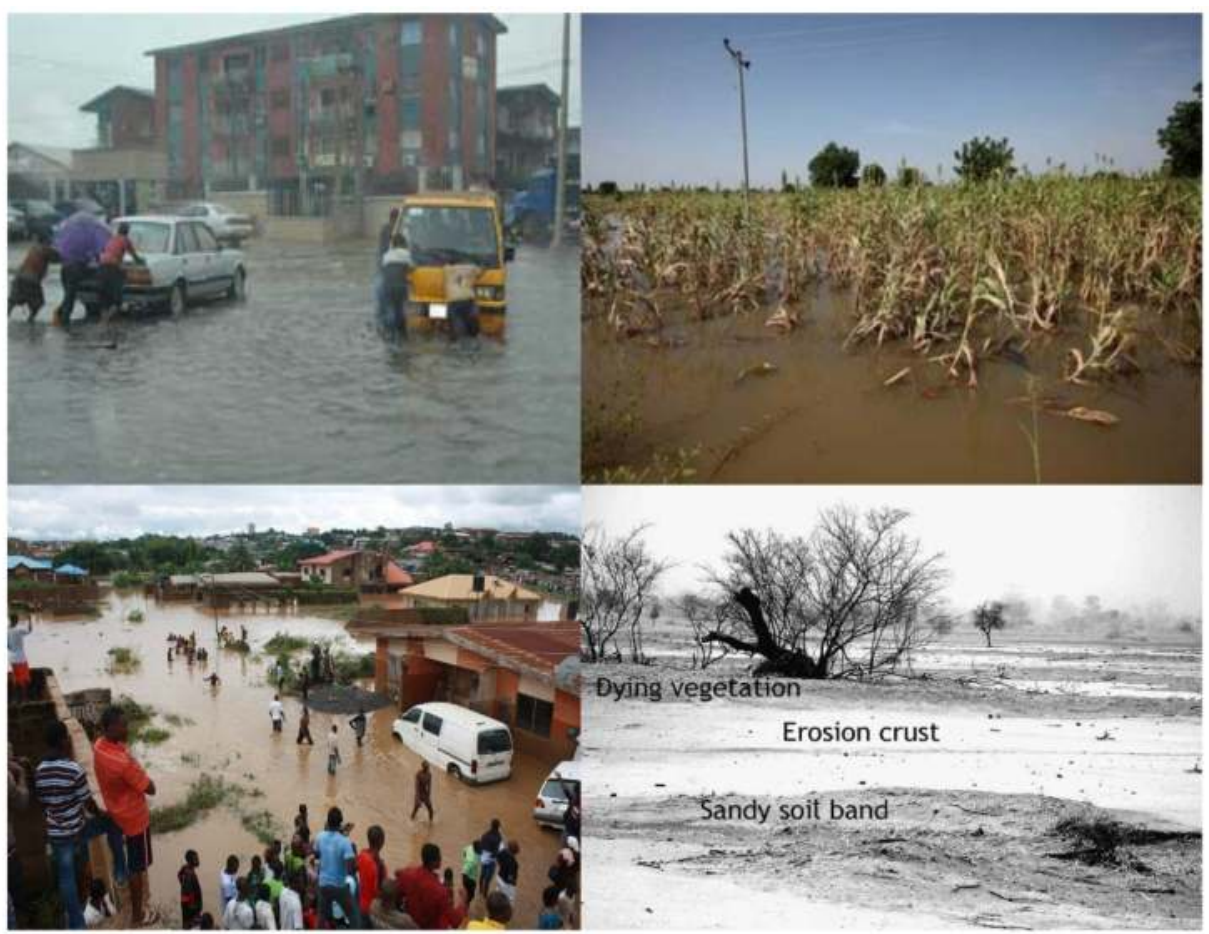

Figure 2. Reaping Extreme Hydrological disasters due to climatic Variability and changing climate (Nigeria experience in the lower Niger Sub-basin)

Water is an indispensable element of life; the water resources of the region's river basins are highly dependable and sensitive to climate variability and change; due to inter-connection between the climate system, hydrological cycle and water resources system. Thus, if the trends in climate contexts that took place over the last three decades continue to prevail unabatedly, West Africa will no doubt experience decreased freshwater availability. Also, compared to previous decades, it is observed that since the early 1970s, the mean annual rainfall has decreased by $10 \%$ in the wet tropical zone to more than $30 \%$ in the Sahelian zone while the average discharge of the region's major river systems dropped by 40 to $60 \%$. This sharp decrease in water availability will be complicated by greater uncertainty in the spatial and temporal distribution of rainfall and surface water resources [2, 3]. Again, it is important to note that Niger River basin is not just simply water; it is an origin of identity for the region, a route for migration and commerce; but also seriously threatened by manmade climate change. The region's recent experience is a demonstration of the fact that climate change is real and not a myth. It is against this backdrop that this paper attempts to highlight the various experiences of the level of vulnerability of Niger River basin and its inhabitants to the impacts of climate change including climatic variability and extremes; as well as provide scientific evidence to substantiate the characterization of the current climatic variability and the future impacts of climate change on the region. So the paper will try to 
distinguish between climate variability and climate change. We adopt the Inter-governmental Panel on Climate Change (IPCC) definitions for both terms. Accordingly, climate change is referred to as statistically significant variation in the mean state of the climate or the long-term changes in climate conditions observable over several decades or longer [4]. Climate variability on the other hand is the deviations of climate statistics over a given period of time from the long-term climate statistics relating to the corresponding calendar period or short-term variations in climate over periods of days, months, years and decades [4].

\section{Intellectual merit}

For a very long period of time there has been harmonious and balanced use of water of Niger River, such that it is even limited in its natural functions and services. But over time, this trend changed, as the basin suffered for many decades from human pressure and new uses such as construction of dams that have been disturbing the characteristics, structure and functioning of the river basin's ecosystems. This intensive use of these natural resources added to the growing population and climate changes impacts, among which severe droughts and their impacts have had severe consequences on the status of the Niger River and its tributaries, biodiversity, landscapes, key habitats and floodplains. Aside this, climate change and freshwater resource systems are interconnected in a complex ways, with rainfall patterns, evaporation and water demand or use influencing the availability of both surface and groundwater resources in the region.

Of course, the climatic future of the Niger River Basin may remain uncertain, due to inconsistency of the global climate models over the area; but climate change is expected to have a major influence not only on water resources, but on food and human society at large through its impacts on climatic variability and extremes. Again, it is impossible to rule out the occurrence of other possible indirect influences of climate change such as higher temperatures leading to high evaporative-and greater-demand for water. Undeniably, such disagreement between the climate models may be interpreted that nothing could be said with certainty about the future evolution of rainfall in the basin; but very high degree of climatic variability is projected to continue, which could even become more pronounced on seasonal, annual and decadal timescale. West African rivers are mainly strongly seasonal and humid with fairly modest inter-annual rainfall variability. As shown in figure 3, the rivers display very strong relationships with rainfall that accounts for about $60 \%-70 \%$ of river flow variability [5]. In all the cases, river flows show much greater coefficient of variability than rainfall mainly because of heterogeneity and nonlinear response of runoff to changes in rainfall; especially to the variations in rainfall intensity. The impacts of climate change on freshwater resources systems can sometimes be direct, stemming from the relationship between temperature and/or precipitation, and the abundance and quality of the available water resources; while the indirect impacts occur by causing shifts in temperature, lifestyle, population, economy or technology, which in turn may trigger shifts in demand for water. Thus, it is expected that climate change could further amplify and entrench water resources anomalies such as local drought or flooding at the lake / river level. 


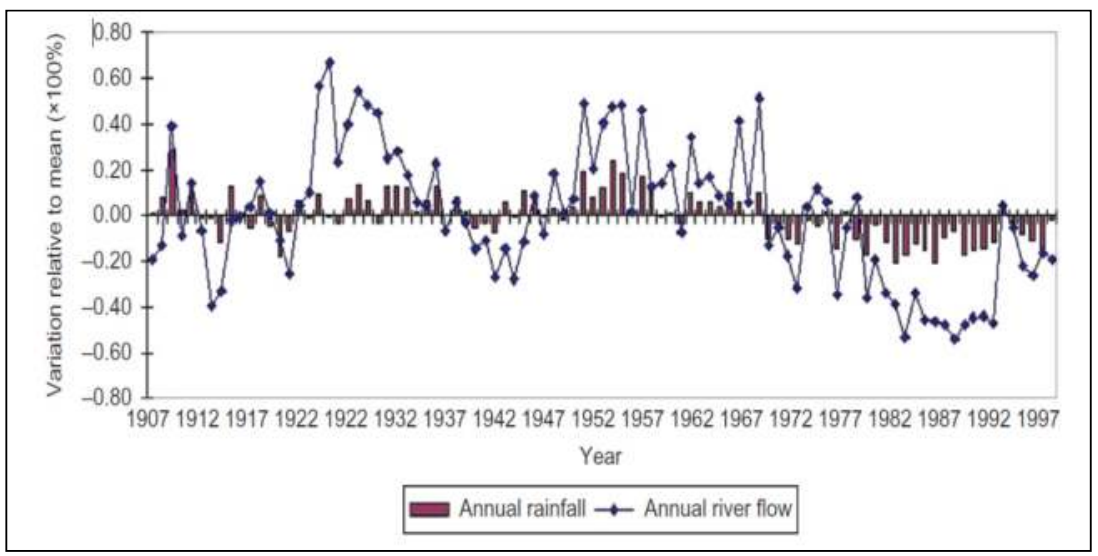

Figure 3. Rainfall-Runoff interactions in Sudano-Guinean zone of Niger Basin in Mali and Guinea (source: Mahel et al., 2009)

According to Intergovernmental panel on climate change (IPCC), climate change is expected to result in severe water stress over much of Africa; particularly, in the agro-pastoralist region of West Africa [6], where Niger River basin is located. Consequently, not only will freshwater become scarcer in already dry regions, but changing freshwater temperatures could affect natural ecosystems and water quality. In fact, the West African region of the continent is characterized by extreme climatic variability with extreme weather events; the last 40 years since 1969 have witnessed dramatic reductions in mean annual rainfall (Fig. 4) throughout the region [7, 8, 9 and 10]. A rainfall decrease of $29-49$ percent has been observed in the $1968-$ 1997 period compared to the 1931 - 1960 baseline period within the Sahel region [6].

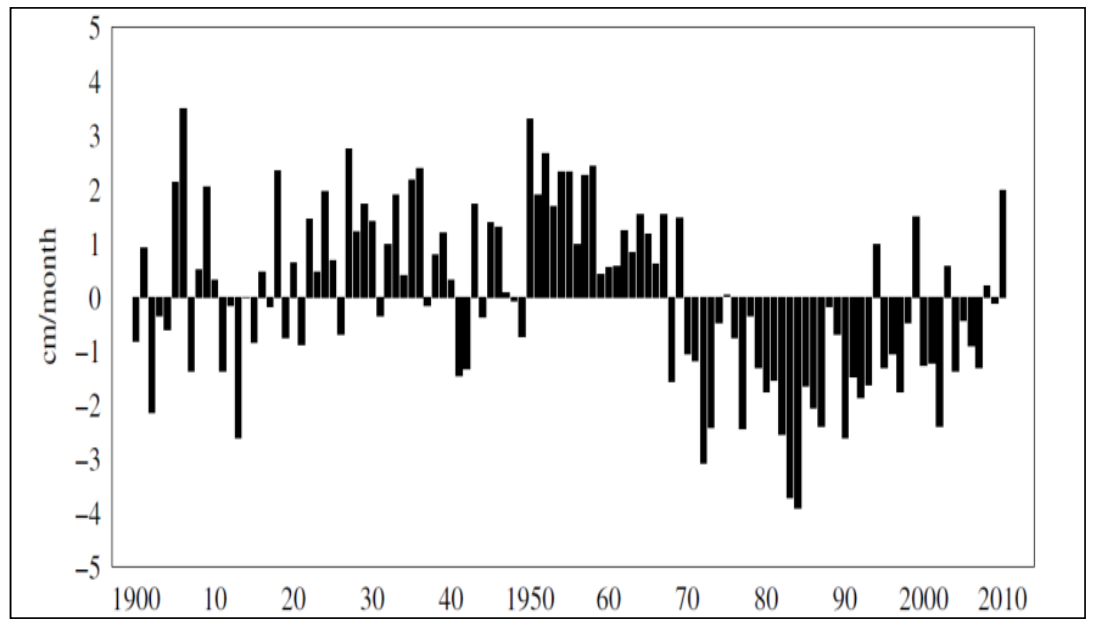

(Source: NOAA NCDC Global Historical Climatology Network Data)

Figure 4. Typical Rainfall Anomalies (1900 -2011) over West African Sudano-Sahel zone (11-18N and West of 10E) 
The projected warming climate caused by increasing concentration of greenhouse gases is very likely to exacerbate the present climatic variability and extremes in the region; which already have implications for water resources availability and food production not only in the Niger River basin, but over the entire West African region. For example, the main livelihood of the people in Niger River basin is traditional, low input, rain-fed farming and nomadic pastoralism; any increase in volatility of summertime temperatures will therefore, have serious effects in grain-growing regions of the basin. Again, climate change is expected to lead to intensification of the hydrological cycle; and by implication will ensue in increasing drought or flooding episodes.

Aside this, the Niger River is not just simply water; it is an origin of identity for the region, a route for migration and commerce, as well as a catalyst for potential conflict and cooperation too. Hence, the rising concern on the adequate management and assessment of the water resources in the face of the changing climate is quite important. The river and its tributaries are the lifeline for the teeming human population, with annual growth rate of 2.8 per cent; as well as the major sources of hydropower to most of the riparian countries within the basin. Much of the population of the basin suffers from extreme, chronic poverty and vulnerable to droughts and increasing malnutrition rate, due to increasing food and water insecurity resulting from climatic, demographic and land use changes.

Climate change is indeed real, not a myth. The region's recent past experience of unusual vagaries of weather and climate is a clear demonstration of reality of climatic variability and change. In fact, climate change represents a shock to the rural farmers' with low resilience to climate change impacts. It in fact poses a pincer threat that reveals how vulnerable the basin and its inhabitants are to hydrological extremes (droughts floods landslides etc.). Today, droughts and floods have become the most common natural disasters in the Niger River basin frequently accompanied by loss of lives, properties and croplands. With climate variability and change, changes in the onset and cessation dates of rainy season are very likely; as presently being experienced in Nigeria (Fig. 5). Almost all the droughts that occurred in the region are associated with late starts of rainy season and early cessation of the rains, resulting in drastic reductions in the length of rainy season and invariably the length of growing season as well.

Under such a context, only a rational mobilization and adequate management of water resources in the River Niger basin seem to be the most adequate answer and the catalyst for the development of growth and gradual alleviation of poverty. Therefore, sustainable water resources and agricultural development has become an absolute necessity for food security and health in $21^{\text {st }}$ century; if poverty eradication is to become a reality in Africa and Nigeria in particular. Additionally, with climate variability affecting the agricultural sector badly, coupled with uncertainty about the future climate that confounds planning among the smallholder and commercial farmers, climate change could aggravate this already tensed situation, triggering unfathomable impacts such as crop failures, floods, droughts and malaria epidemics. This will no doubt compromise the region's ability of achieving the Millennium Development Goals (MDGs) related to poverty, hunger and human health. Climate change will further pose serious challenge to the attainment of other MDGs related 
to reduce child mortality, improved maternal health, ensuring environmental sustainability and combating HIV/AIDS, malaria and other diseases as a result of malnutrition ensuing from food insecurity. Thus, the need for anticipatory strategies for adaptation to climate variability and change has become even more urgent as resources demands increase through population growth and development.
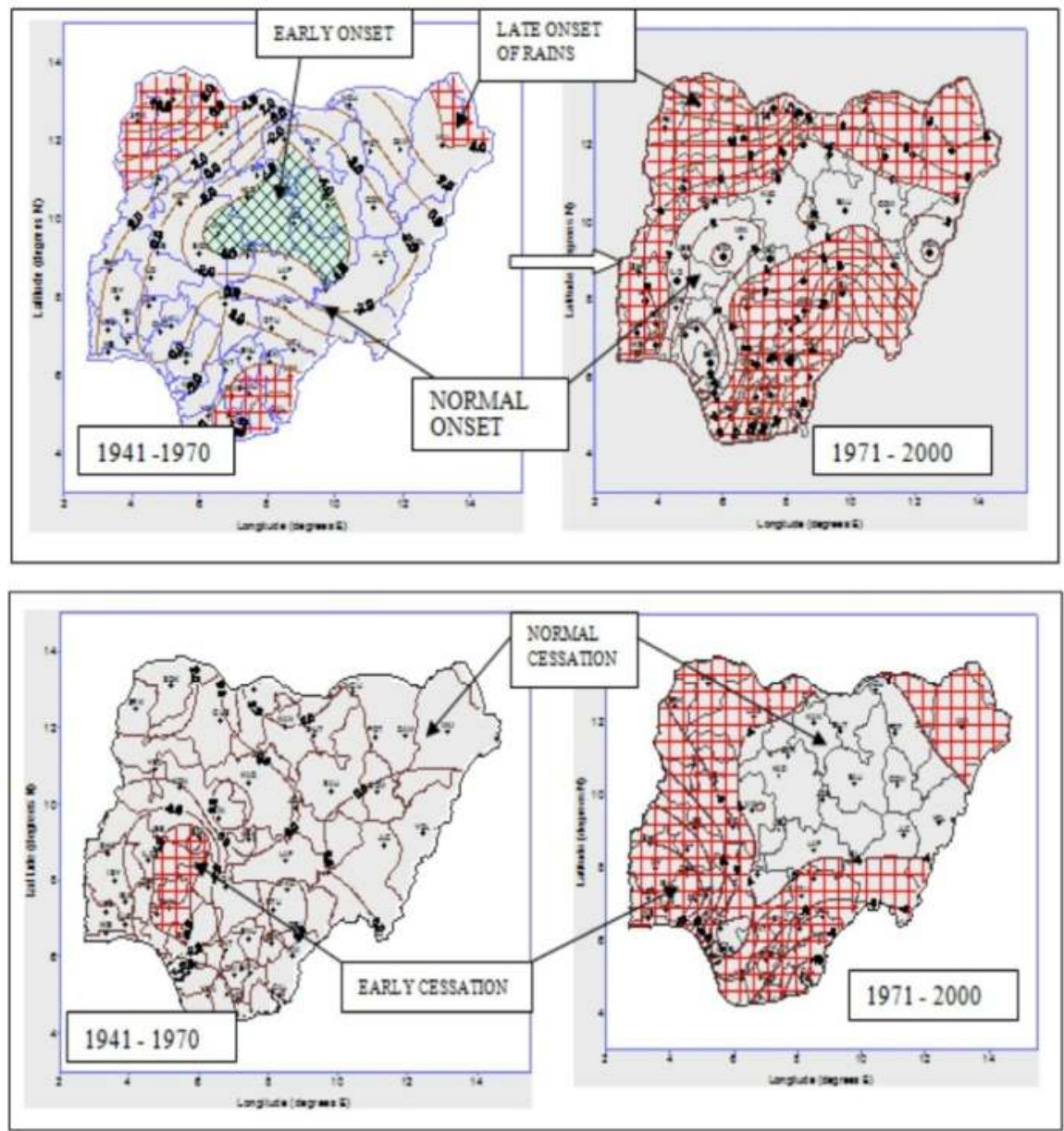

(Source: Nigeria Meteorological Agency (NIMET, 2007))

Figure 5. Fig. 5: Changes in Onset (top) and Cessation (bottom) Dates of Rainy Season (Nigeria)

Number of studies in the Niger basin have shown significant trends towards a false onset (a situation where the rainy season starts normally and then ceases abruptly, creating a dry period between the false onset and the true onset), late or delayed onset (a situation where the expected start of the rainy season is delayed) and early cessation (a situation where the rainy season stops far ahead of the expected time of the summer rains) [8]. For example, 
prolonged drought occurred from 1738-1756, centred in the area of the Niger River bend that induced famines which killed half of the population of the city of Timbuktu. More recently too, there has been persistent drought in the Sahelian regions of the basin since the late1960s that has resulted in a decrease in the availability of freshwater resources [6]. Up to 250,000 people and millions of herds of cattle are reported to have perished. In the lower Niger sub-basin(Nigeria) alone, the impacts of the drought episodes of 1968 and 1973/74 which reduced agricultural yields between $12 \%$ and $14 \%$ of annual average and ensued in death of about 300,000 animals representing $13 \%$ of livestock population was still being felt several years after[11]. So, the impacts of drought are extremely serious and often dramatic particularly for the most vulnerable groups - women and children. Drought forces the inhabitants of the Nigerian dry lands to resort to survival strategies, which further exacerbate the desertification problems, with associated reduction in land productivity and worsening poverty problems. Some other major famines also occurred from 1983 - 1985 and 2007 in large sections of the Niger basin. This was well documented in the IPCC's 2007 Fourth Assessment Report, confirming its earlier findings, which shows that trends in Africa include a rise in average temperature of $0.7^{\circ} \mathrm{C}$ for most of the continent during the $20^{\text {th }}$ century, and decreases in rainfall of up to 30 percent over large portions of the Sahel. In Niger River basin, it further documents that the rivers mean annual discharge declined by 40-60 per cent; and in future, the basin could see changes in rainfall, evaporation and runoff of approximately 10 per cent. Also, major changes in rainfall in terms of annual and seasonal trends and extreme events of flood and drought have been documented by [12, 13, 14 and 6]. Other parts of the West Africa is not left out; for example, annual hydrological regime of the Nakambe River, Burkina Faso has shown substantial changes too during the period19551998 with a shift occurring around1970[15].

Moreover, while most research and action have focused on drought challenges and its impacts in the Sahel it is important to also state that the region also experiences periodic flooding. In 1953 or there about, heavy rainfall leading to flooding destroyed crops and resulted in famine that lingered on for the first nine months of 1954. This affected about five million people in both western and south-central Niger and northern Nigeria and northern Cameroun [16]. Since the recovery of the Sahel rainfall in the mid-1990s following the prolong drought periods of 1970s and 1980s[17],floods associated with intense rainfall have again become more pronounced in the region, most notably in 1995, 1998-1999, 2002-2003, 2006-2008 and 2010[18]. This resurgent of flood phenomenon has been associated with a number of factors; including anomalous heating in the tropical Atlantic Ocean and La-Nina event in the tropical Pacific Ocean[19]. This argument on whether such intense rainfall can lead to flooding was further substantiated by linking the occurrence of the floods to accumulative rainfall in the days prior to heavy rain event [20]. Also two distinct flood events occur every year in the Niger basin, especially in the lower sub-basin in Nigeria. The first is the 'black flood' that originates from the high rainfall area at the headwaters; arriving at Kainji (Nigeria) every November and lasting till March at Jebba (Nigeria) after attaining a peak of about $2000 \mathrm{~m}^{3} / \mathrm{s}$ every February. The second type of flood is called 'white flood', 
which becomes prominent only downstream of Sabongari (Nigeria), soon after Niger River enters Nigeria; usually laden with silt and other suspected particles. The flood derives its flow from the local tributaries and reaches Kainji every August and attaining peak rate of $4000-6000 \mathrm{~m} 3 / \mathrm{s}$ between September and October in Jebba every year [21]. How all these flood and droughts events will evolve in future in the face of the changing climate still remains a subject of research till today.

Till today, there has been increasing menace of frequency of flood in the lower Niger basin, due to intense falls of short duration particularly for the years - 2005, 1999, 1994 and 1988 and the resulting casualties are all still very fresh in mind. For instance, in August, 2005, the old Nukkai Bridge in Jalingo State, Nigeria, collapsed and sank into the overflowing Jalingo River, killing more than 100 people (ThisDay newspaper, 2005). Most recently too is the collapse of Sokoto bridge, Nigeria in 2010 in the same manner the Minneapolis Bridge collapsed and sank into Mississippi River in USA; on $2^{\text {nd }}$ August, 2007 (http://www.washingtonpost.com/wp-srv/photo/gallery/070801/GAL-07Aug01-833303/ind ex.html), all due to massive flooding from intense rainstorms ensuing from a changing climate, because these bridges were initially designed for passage of specific discharge of flood water that may be far less than the discharge that it is presently able to convey. These bridges were designed on the assumption of stationarity of hydrological series and return period. With climate change, the assumption of stationarity of series in hydraulic design of water resources system is dead [22]. With hydrological cycle projected to intensify in the face of the changing climate, these hydrological extremes (droughts and floods) are expected to be on the increase [6].

With increasing climatic variability, climate change will impose additional pressures on the water availability, water accessibility and water demand in the region; although the scant available data in the region make it presently difficult to predict these changes with recognizable certainty [6]. Also, observed is the consequent collapse of the region's ecological zones from 6 (Table 1) to 5 (Fig. 6), as a result of decline in rainfall; there has been $200 \mathrm{~km}$ southward shift in isohyets (Fig. 7). Following the decline in average annual rainfall, before and after 1970, with ranges from $15 \%$ to over $30 \%$ depending on the location within the Niger basin[23], the savanna zone (interface of desert and forest) is resultantly pushed further south with the desert advancing at a fast rate of $700 \mathrm{~m}$ per annual on the average. Hence, we now have the Sudano/Sahel extending to about lat: $10.5 \mathrm{~N}$ from lat: $12.5 \mathrm{~N}$, covering about $35 \%$ of the landmass of the country.

Furthermore, evidence of changing climate and its effects on local hydrology can already be seen in the historic stream flow records of the Niger River. Records have shown substantial decrease in observed flows across the basin over a time period from 1907 to 2000, due primarily to increasing temperature. A minimum zero flow condition was observed in 1985 over Niamey (Niger) Gauging station (Table 2), at the upstream of Nigeria [24]. Even in the humid lower Niger sub-basin, the average river flow of the recent time slice (1982-2000) in table 3 is far lower than the previous reference time period (1960-1981). The logical consequence of a decline in precipitation and streamflow is a change in the timing and magnitude of the precipitation and streamflow pattern. 


\begin{tabular}{|l|l|l|l|l|l|}
\hline $\begin{array}{l}\text { Ecological } \\
\text { Zones }\end{array}$ & $\begin{array}{l}\text { Altitude } \\
\text { in(m) }\end{array}$ & $\begin{array}{l}\text { Mean Monthly } \\
\text { Temperature }\left({ }^{\circ} \mathrm{C}\right)\end{array}$ & $\begin{array}{l}\text { Mean Annual } \\
\text { Rainfall(mm) }\end{array}$ & $\begin{array}{l}\text { Type of } \\
\text { Rainfall } \\
\text { Distribution }\end{array}$ & $\begin{array}{l}\text { Length of } \\
\text { Rainy Season } \\
(\text { days })\end{array}$ \\
\hline $\begin{array}{l}\text { Mangrove } \\
\text { Forest and/ } \\
\text { Freshwater } \\
\text { Swamp Forest }\end{array}$ & $<100$ & $28-25$ & $>2000$ & $\begin{array}{l}\text { Extended } \\
\text { Modal }\end{array}$ & $300-360$ \\
\hline Rain Forest & 100 & $28-24$ & $1200-2000$ & Bimodal & $250-300$ \\
\hline $\begin{array}{l}\text { Derived } \\
\text { Savanna and } \\
\text { /Southern } \\
\text { Guinea } \\
\text { Savanna }\end{array}$ & $<500$ & $30-26$ & $1100-1400$ & Bimodal & $200-250$ \\
\hline $\begin{array}{l}\text { Northern } \\
\text { Guinea } \\
\text { Savanna }\end{array}$ & $400-500$ & $30-23$ & $1000-1300$ & Unimodal & $150-200$ \\
\hline $\begin{array}{l}\text { Sudan } \\
\text { Savanna }\end{array}$ & $<300->600$ & $31-21$ & $600-1000$ & Unimodal & $90-150$ \\
\hline $\begin{array}{l}\text { Sahel } \\
\text { Savanna }\end{array}$ & $300-400$ & $32-25$ & $400-600$ & Unimodal & 90 \\
\hline
\end{tabular}

Table 1. Characteristics of the ecological zones over West Africa

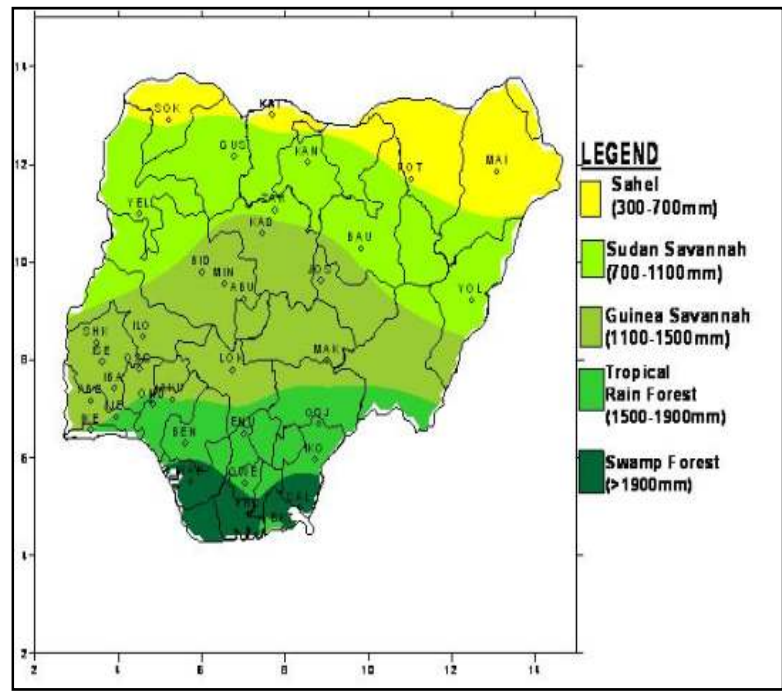

Figure 6. Collapsed Ecological Zone of Nigeria from 6 in table 1 to 5 zones due to changing climate 


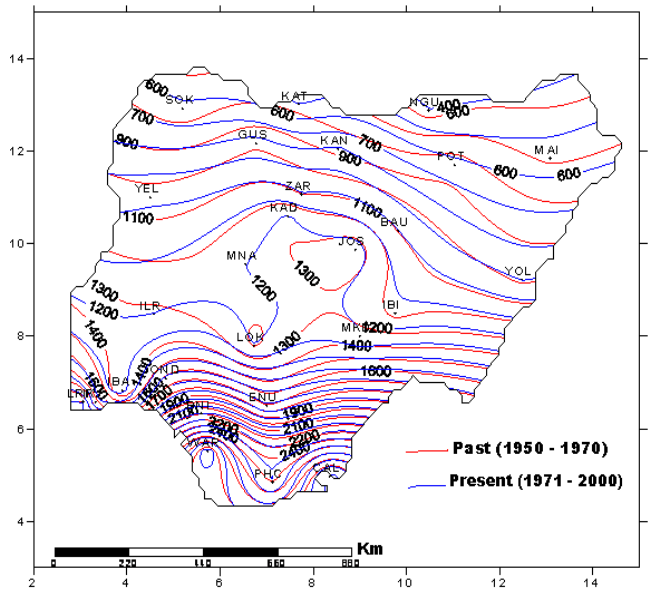

Figure 7. Isohyets shift due to southward advancing of aridity

\begin{tabular}{|l|l|l|l|l|l|l|l|}
\hline Station & River & Period & $\begin{array}{l}\text { Qmean } \\
\left(\mathrm{m}^{3} / \mathrm{s}\right)\end{array}$ & $\begin{array}{l}\text { Qmax } \\
\left(\mathrm{m}^{3} / \mathrm{s}\right)\end{array}$ & Year & $\begin{array}{l}\text { Qmin } \\
\left(\mathrm{m}^{3} / \mathrm{s}\right)\end{array}$ & Year \\
\hline $\begin{array}{l}\text { Koulikoro } \\
(\text { Mali })\end{array}$ & Niger & $1907-2000$ & 1385 & 9670 & 1925 & 13 & $\begin{array}{l}1973 \text { and } \\
1982\end{array}$ \\
\hline $\begin{array}{l}\text { Niamey } \\
\text { (Niger) }\end{array}$ & Niger & $1928-2000$ & 870 & 2360 & 1968 & 0 & 1985 \\
\hline $\begin{array}{l}\text { Lokoja } \\
\text { (Nigeria) }\end{array}$ & Niger & $1915-2000$ & 5590 & 26,300 & 1956 & 599 & 1974 \\
\hline
\end{tabular}

Table 2. Discharge Characteristics of River Niger (Source: Archives of HYDRONIGER)

\begin{tabular}{|l|l|l|l|l|l|l|l|}
\hline Station & River & Period & Qmean $\left(\mathrm{m}^{3} / \mathrm{s}\right)$ & Qmax $\left(\mathrm{m}^{3} / \mathrm{s}\right)$ & Year & Qmin $\left(\mathrm{m}^{3} / \mathrm{s}\right)$ & Year \\
\hline Lokoja & Niger & $\begin{array}{l}1960-1981 \\
1982-2003\end{array}$ & $\begin{array}{l}68936.5 \\
58646.9\end{array}$ & $\begin{array}{l}94790 \\
(1960-2003)\end{array}$ & 1969 & 25760 & 2003 \\
\hline Onitsha & Niger & $1960-1981$ & $\begin{array}{l}71136.64 \\
59721.14\end{array}$ & $\begin{array}{l}87810 \\
(1960-2003)\end{array}$ & 1999 & 25760 & 2003 \\
& & $1982-2003$ & & & \\
\hline Makurdi & Benue & $1960-1981$ & 41369.21 & $\begin{array}{l}61869 \\
(1960-2000)\end{array}$ & 1969 & 20378 & 1983 \\
\hline Jebba & Niger & $1982-2000$ & 34660.84 & $\begin{array}{l}23377 \\
(1960-1997\end{array}$ & 1963 & 6253 & 1991 \\
\hline
\end{tabular}

Table 3. Lower Niger River flow Characteristics

Again, the need for development and investment in the region is evident too, and the Niger River holds tremendous development potentials. Development opportunities range from 
those directly related to the river, such as power, irrigation, and navigation, to those "beyond the river," such as increases in trade, communication investments, and enhanced labor flows [25]. However, despite the rich potentials of the basin, the basin has not been meeting the rising water demands of the region occasioned by high population growth rate, which is projected to double by 2050 as shown in Figure 8[26]. This clearly reveals the high vulnerability of the basin to climatic variability and potential climate change. This is because water availability in Niger basin is highly variable, aside the growing concern on land and water degradation occasioned by climate change and human activities. Also threatened is groundwater, which is found to be safer than surface water, especially concerning pollution vulnerability. Consequently, there has been threat of tension between the Member States of the basin, underscoring the need for equitable sharing of water resources [27]. Hence, studies of this kind is conceptualized as a means of informing and improving knowledge of the availability of water for food production and equitable management and sharing of the natural resources, since water is the source of food security. To worsen the already fragile situation, deforestation too is progressing at an alarming rate due to urbanization and population pressure. By 2000, tropical forest and woodland covered less than $15 \%$ of the land mass [28].

Another issue of great concern is the gas flaring, which contributes to global warming, the main culprit of climate change, apart from causing other environmental degradations. The flaring of gas has been practiced in the Niger Delta region in the lower Niger sub-basin for over four decades (Fig. 9). Today there are about 123 flaring sites in the region (Energetic Solution Conference, 2004), making Nigeria one of the highest emitter of greenhouse gases in Africa. For example, some 45.8 billion kilowatts of heat are discharged into the atmosphere of the Niger Delta from flaring 1.8 billion cubic feet of gas every day [29].

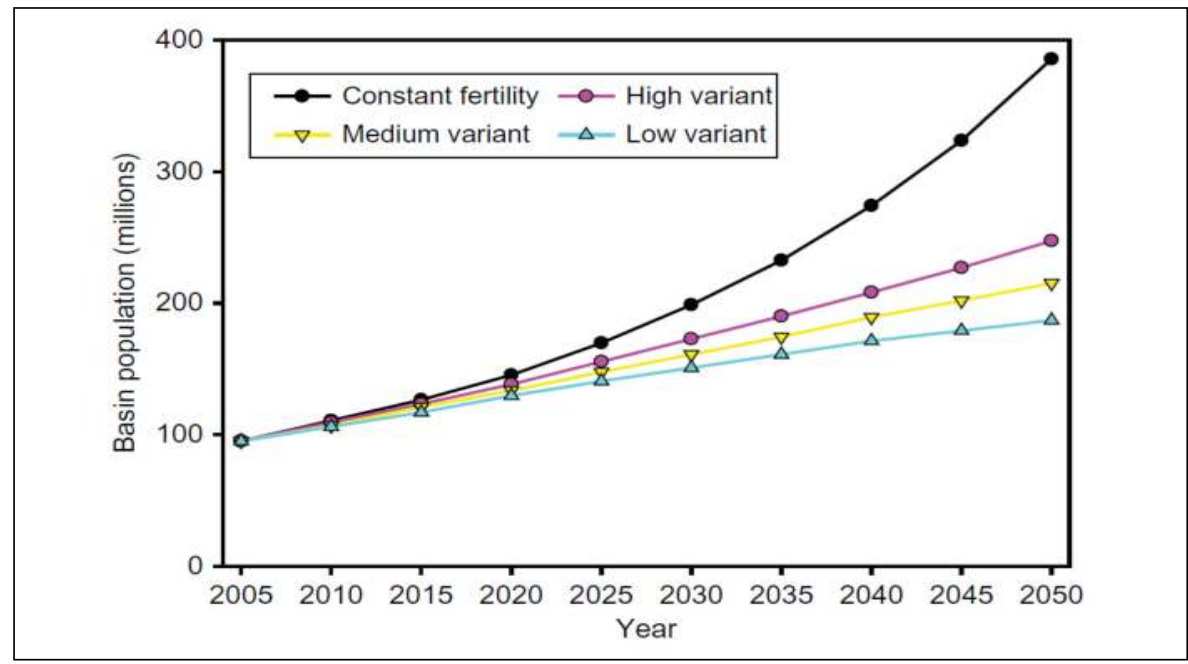

Figure 8. The evolution of Niger River Basin population 2005-2050(Source: based on UN population Division (2006) 
Gas flaring has raised temperatures and rendered large areas uninhabitable. Between 1970 and 1986, a total of about 125.5 million cubic meters of gas was produced in the Niger Delta region, about $102.3(81.7 \%)$ million cubic meters were flared while only 2.6 million cubic meters were used as fuel by oil producing companies and about 14.6 million cubic meters were sold to other consumers [30]. Gas flaring and other oil exploration and exploitation activities have contributed significantly to the degradation of the environment in the region. Gas flaring leads to acid rains; and the concentration of acid in rain water appears to be higher in the Niger Delta region and decreases further away from the region. Though there is need to do more research on this. It has altered the vegetation of the area, replacing local vegetation with "stubborn" elephant grasses, as it is called locally, a grass plant that can grow in very harsh environment. Unfortunately, in spite of the negative implications of gas flaring to the environment, the multi-national oil firms operating in Nigeria have continued in these bad environmental practices unabatedly.

Although, recent studies suggest that increase in atmospheric concentration of GHG on West Africa from current elevated levels up to about 550ppm, may make West Africa rainfall regime more robust and drought less frequent and persistent (Brook, 2004). So there is need to assess how much impacts the future change would have on the local and regional available water resources.

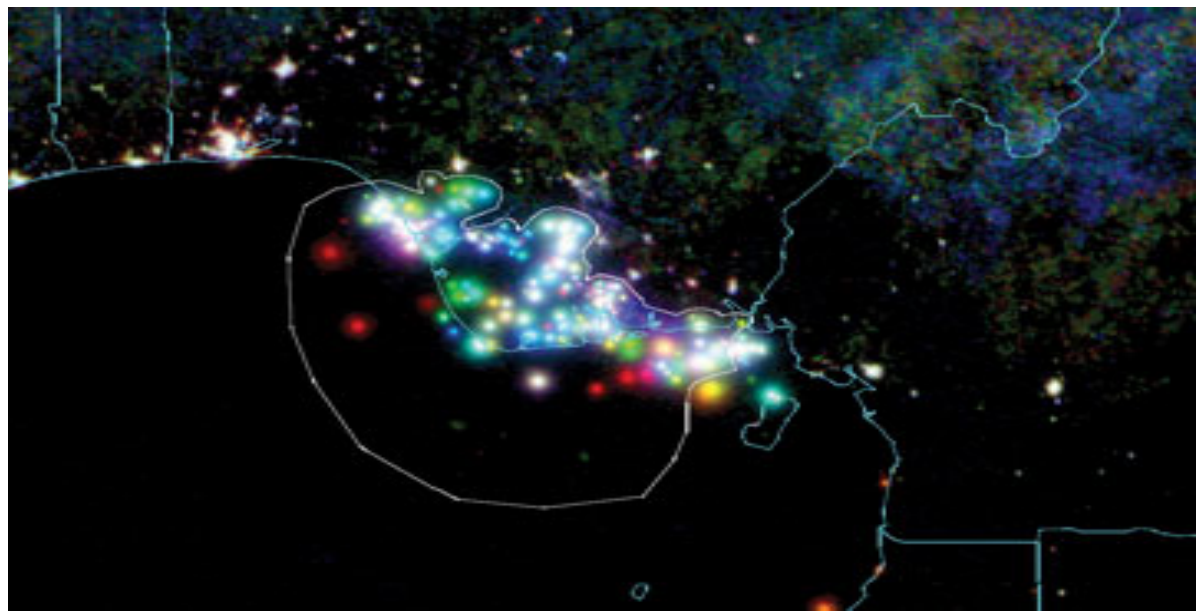

Figure 9. Satellite image shows Nigeria's coastline burning bright with gas flares at night. The red dots represent gas flared in 2006, the green dots represent 2000 and the blue dots represent 1992. The white line encircles the flares associated with Nigeria.

Drawing on a review of published literature on Niger Basin, it is observed that though the assessment of the impacts of climate change on hydrology and water resource is given accelerated attention in most parts of world today, not much of research works have been done to assess quantitatively the impact of the projected climate change on water resources, socio-economic activities and hydrological extremes in the region. Also, since the majority of the basin lies in the Sahel zone (between lat. $10^{\circ} \mathrm{N}$ and $20^{\circ} \mathrm{N}$ and long. $20^{\circ} \mathrm{W}$ and $10^{\circ} \mathrm{E}$ ), 
researches on characterization of current climatic variability and future climate change have been lopsided focusing more on the Sahel. Less published information is available for the more humid portions of the basin [17], underscoring the reason for focusing on the lower Niger sub-basin in this study. However, amongst the few studies available include the work of reported in [31], 32, 33, 34 and 35]. Also, an average temperature increase of $0.4^{\circ} \mathrm{C}$ has been observed within Nigeria over the 20 years [36]; while climatic variations were observed over Benin - Owena River Basin, southwestern, Nigeria that appears as fluctuations of wet and dry periods every 2-3 years in terms of rainfall and stream flow [37], with a positive temperature trend rising at the rate of $0.37^{\circ} \mathrm{C} /$ decade. Also, observed is a decreasing trend of rainfall over Lake Chad basin[38] and it was opined that climatic change apart from some other human activities (irrigation) was the main key factor responsible for the shrinkage of the Lake size from $25,000 \mathrm{~km}^{2}$ in the 1960 s to presently barely $2,000 \mathrm{~km}^{2}$.

\section{Application area}

The case study area being investigated is the Niger River basin with much focus on the lower Niger sub-basin area, a much humid portion of the Niger River basin where Nigeria is domiciled and less researched by climate change scientists. River Niger is located between $5^{\circ} \mathrm{N}$ and $23^{\circ} \mathrm{N}$ of latitude, and $12^{\circ} \mathrm{W}$ and $17^{\circ} \mathrm{E}$ of longitude. It rises in Guinea high grounds and flows for a total length of about 4,100 km through Mali, Niger and Nigeria before reaching the Atlantic Ocean. Niger River basin is the largest trans-boundary basin in West Africa, and the second largest river in Africa by discharge volume $\left(5,700 \mathrm{~m}^{3} / \mathrm{s} ; 1948-2006\right)$ after Congo River $\left(42,000 \mathrm{~m}^{3} / \mathrm{s}\right)$ and the third longest $(4,100 \mathrm{~km})$. The total drainage area of Niger River (2.2 million $\mathrm{km}^{2}$ ) [39], with hydrologically active area (1.5 million $\left.\mathrm{km}^{2}\right)$ [40] covers fully 7.2 per cent of the continent Africa with a total population of over 100 million people distributed among the nine riparian countries [40] that share the basin's resources of which 71 per cent live in Nigeria. The nine countries presently sharing the active catchment area are; Benin, Burkina Faso, Cameroon, Chad, Cote D'Ivoire, Guinea, Mali, Niger and Nigeria (Fig.10), Seventy-six per cent of the basin area is located within Mali (Upper Niger), Niger (Middle Niger) and Nigeria (Lower Niger) sub-basins.

About $44.2 \%$ of the basin area is located within Nigeria, which constitute about $61.5 \%$ of human population of the basin [26]. According to the lowest climate change scenario, demographers estimated that the population of the basin will double by 2050, but if the present fertility rates remain constant, the population could even increase fourfold by 2050 (Fig. 8). The choice of lower Niger as the focus stems from the fact that Nigeria is strategically located at the downstream of the basin and more vulnerable to the adverse impacts of environmental changes at the upstream, apart from gas flaring and other forms of environmental degradation taking place in Nigeria The region is also less researched in terms of climate change vulnerability and impacts studies. Moreover, Nigeria' ecological strata truly represents the climatic profile of the basin. As shown in figure 11, the climatic zones of Niger Basin varies from hyper-arid in the north to sub-equatorial and annual rainfall fluctuates from about $4000 \mathrm{~mm}$ in the southern/Cameroun to less than $400 \mathrm{~mm}$ ( with 


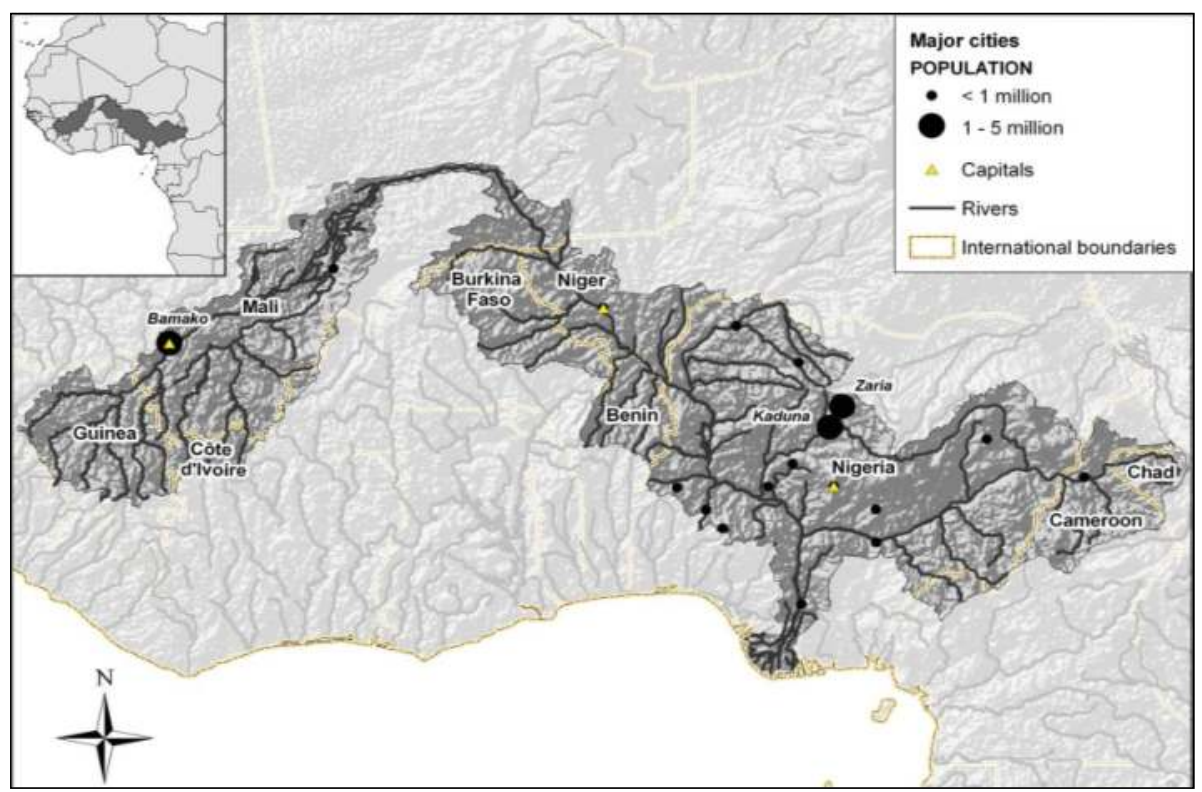

Figure 10. Niger River Basin Catchment Area and Member countries

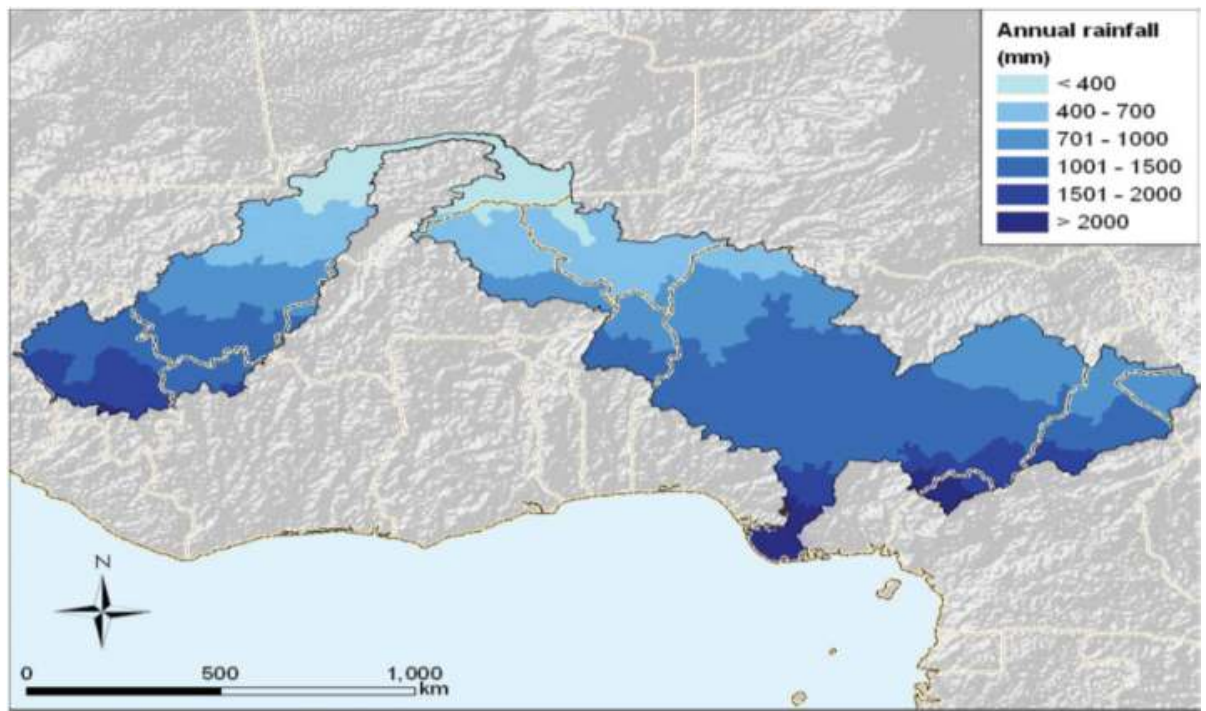

Figure 11. The Niger Basin annual rainfall (source: Mahe et al., 2009a)

no rain in some years) on the fringes of the Sahara desert in northern Mali and Niger [26]. Spatio-temporal variability of rainfall is high in the basin, causing water stress and droughts, which are very problematic for agricultural planning than low annual rainfall [41] also cited in [26]. Rain-fed agriculture remains a common practice in the region. Total 
rainfall provides a measure of water supplied to rain-fed agriculture on a given area; while evapotranspirable water corresponds to the fraction of rainfall actually available to the plants and excludes rain that falls when the plants cannot exploit it or in excess of the demand. That said, northwards from the very humid, eastern coastal locations, to the boundary with the desert, the vegetation profile includes Moist Evergreen Rain Forests, Dry Semi-Evergreen Rain Forests, Derived Savannah, Southern Guinea Savannah, Northern Guinea Savannah, Sudan Savannah, and Sahel Savannah [42, 43]. Rainfall in Niger River basin depends on the Atlantic West African monsoon (WAM) between May and November each year and gives dry and wet seasons respectively.

Another important index of climate change posing serious challenge in the basin is the land use/ land cover changes. Land cover just like in any other part of the global environments results mostly from combination of natural and anthropogenic influences. The main natural force of the change remains rainfall changes induced by climatic variability. This has been found to often reduce the natural regeneration rate of land resources in the area. Table4 shows the percentage of changes that took place between 1976 and 1995 in Nigeria.

\begin{tabular}{|c|c|c|c|c|c|}
\hline $\mathbf{S} / \mathbf{n}$ & Eeology & Area km2 (1976) & Area $\mathrm{km} 2$ (1995) & Change 1976-1995 & Percent change \\
\hline 1 & Agricultural Tree Crop Plantation & 824.15 & $1,656.88$ & 832.73 & 101.0 \\
\hline 2 & $\begin{array}{l}\text { Alluvial } \\
\text { Discontinuous grassland dominated by grasses and }\end{array}$ & 523.61 & 282.38 & -241.23 & -46.1 \\
\hline 3 & bare surfaces & $7,614,72$ & $12,517.23$ & $4,902.51$ & 64.4 \\
\hline 4 & Disturbed Forest & $14,677.70$ & $19,491.29$ & $4,813.59$ & 32.8 \\
\hline 5 & $\begin{array}{l}\text { Dominantly grasses with discontinuous shrubs and } \\
\text { scattered trees } \\
\text { Dominantly shrubs and dense grasses with a minor tree }\end{array}$ & $13,053,77$ & $12,487.62$ & $-566,15$ & -4.3 \\
\hline 6 & & $118,529.55$ & $85,020.98$ & $-33,508.57$ & -28.3 \\
\hline 7 & subdominant grass component & $154,933.40$ & $83,281.15$ & $-71,652.25$ & -46.2 \\
\hline 8 & $\begin{array}{l}\text { Extensive (grasing, minor row erops) Small Holder } \\
\text { Rainfed Agriculture }\end{array}$ & $170,837.55$ & $192,892.33$ & $22,054.77$ & 12.9 \\
\hline 9 & $\begin{array}{l}\text { Extensive Small Holder Rainfed Agriculture with } \\
\text { Denuded Areas }\end{array}$ & $4,417.88$ & $10,118,47$ & $5,700.58$ & 129.0 \\
\hline 10 & Floodplain Agriculture & $9,671.81$ & $21,576.03$ & $11,904,21$ & 123.1 \\
\hline 11 & Forest Plantation & $1,000,85$ & $1,581,24$ & 580.39 & 58.0 \\
\hline 12 & Forested Freshwater Swamp & $18,564.71$ & $16,696.51$ & $-1,868.20$ & -10.1 \\
\hline 13 & Graminoid/Sedge Freshwater Marsh & $5,882,74$ & $1,136.51$ & $-4,746.22$ & -80.7 \\
\hline 14 & Grassland & $1,196.74$ & $8,146,74$ & $6,950.00$ & 580.7 \\
\hline 15 & Gullies & 125.35 & $19,070.48$ & $18,945.13$ & $15,113.2$ \\
\hline 16 & Intensive (row crops & $329,227,97$ & $373,481.34$ & $44,253.37$ & 13.4 \\
\hline 17 & Irrigation Project & 148.85 & $1,008.86$ & 860.01 & 577.8 \\
\hline 18 & Livestock Project & 51.02 & 139,65 & 88.63 & 173.7 \\
\hline 19 & Major Urban & $1,102.58$ & $1,362.37$ & 259.79 & 23.6 \\
\hline 20 & Mangrove Forest & $10,157.12$ & $10,067.31$ & -89.81 & -0.9 \\
\hline 21 & Minor Urban & 958.69 & $4,022.98$ & $3,064,29$ & 319.6 \\
\hline 22 & Montane Forest & $7,900.02$ & $8,053.76$ & 153.74 & 1.9 \\
\hline 23 & Montane grassland & $2,502,27$ & $3,898.15$ & $1,395.88$ & 55.8 \\
\hline 24 & Natural Waterbodies: Ocean & $6,766.53$ & $15,588.36$ & $8,821.83$ & 130.4 \\
\hline 25 & Rainfed Arable Crop Plantation & 15.92 & 521.38 & 505.46 & 3.174 .9 \\
\hline 26 & Reservoir & $1,331,41$ & $2,901.16$ & $1,569.75$ & 117.9 \\
\hline 27 & Riparian Fores & $7,506.46$ & $5,330,46$ & $-2,176.01$ & -29.0 \\
\hline 28 & Rock Outcrop & $1,445.15$ & $2,647.96$ & $1,202.81$ & 83.2 \\
\hline 29 & Sal tmarsh/Tidal Flat & 18,84 & 596.92 & 578.08 & $3,067.5$ \\
\hline 30 & Sand Dunes/Aeolian & $1,032,77$ & $5,428,30$ & $4,395,53$ & 425.6 \\
\hline 31 & Shrub/Sedge/Graminoid Freshwater Marsh/Swamp & $17,749.63$ & $10,251.68$ & $-7,497.95$ & -42.2 \\
\hline 32 & Teak/Gmelina Plantation & 624.44 & $1,156.43$ & 531.99 & 85.2 \\
\hline 33 & Undisturbed Forest & $28,022,42$ & $13,477.90$ & $-14,544,52$ & -51.9 \\
\hline 34 & Canal & & 30.76 & 30.76 & \\
\hline 35 & Mining Areas & & 61.15 & 61.15 & \\
\hline
\end{tabular}

Table 4. Typical Land use/land cover changes in Niger River Basin from 1976-1995 (lower Niger Basin) (Source: Fasona and Omojola, 2005) 


\section{Study design and methodology}

\subsection{The characterization of current climatic variability in Niger River Basin}

There are many different ways by which changes in hydro-climatological series can take place, either abruptly (step change) or gradually (trend) or may even take more complex dimension. The characterization of current climate of the basin is based on the data available in the archives of the Nigerian Meteorological Agency (NIMET), generated from the synoptic weather stations. The length of data used is 62 years (1941-2002), which is within the WMO recommendation of $>50$ years for change detection [44] Using these data, the characterization of the spatio-temporal variability of the basin was examined based on parametric (Regression) and non-parametric (Kendall Rank correlation, Thie and Sens) approaches. Before this is done, the regionalization of the point climatic data into areally integrated climate data using ArcGIS Thiessen Polygon method was done. The regional index employed in the study is calculated as the average of the standardized climatic variables of the stations included in the region. The index is calculated at the monthly and yearly time-scales. The uses of standardized values are important to allow comparison of time-series whenever climatic variables present significant spatial gradient throughout the area of study as in the case in the Niger basin. The standardized variable is expressed as:

$$
Z=(\bar{X}-\mu) / \sigma
$$

where $\bar{X}$ is sample annual rainfall mean for the rainfall station, $\mu$ is the long term mean and $\sigma$ is the standard deviation of long term annual rainfall.

The baseline data used for all the computation is WMO recommended period $1961-1990$. Apart from ensuring compliance with World Meteorological Organization [45] standard, this analysis is necessary to eliminate part of the local variability factors associated with a specific station and not reflected by a regional change. Due to the relevance of such study in water resources management, the year considered in the analysis is standard hydrological year applicable in Nigeria (i.e. $1^{\text {st }}$ June $-31^{\text {st }}$ May). Following the characterization of the current climatic variability, the potential impacts of future climate change on the hydrology and water resources of the region was evaluated using the Thornthwaite water balance and Artificial Neural Networks (ANNs). Given the huge size of the basin within Nigeria $\left(562,372 \mathrm{~km}^{2}\right)$, its heterogeneous nature in terms of agro-ecological zoning and diverse hydroclimatic variability, the whole study area was be divided into five(5) sub-basins, namely: Upper Niger Sub-basin $\left(131,600 \mathrm{Km}^{2}\right)$, Lower Niger Sub-basin $\left(158,100 \mathrm{Km}^{2}\right)$, Niger south Sub-basin $\left(53,900 \mathrm{Km}^{2}\right)$, Upper Benue Sub-basin $\left(158,900 \mathrm{Km}^{2}\right)$, and Lower Benue Sub-basin $\left(73,000 \mathrm{Km}^{2}\right)$.

\subsection{Hydrological modelling of potential impacts of Future climate change on Lower Niger River Basin}

Water balance model description and data source

The water balance model used was the one developed by Thornthwaite in 1948 and later revised in 1955[46]. The method is basically a book-keeping procedure, which estimates the 
balance between the inflow and outflow of water. The main inputs into the model are precipitation and potential evaporation, while the main outputs are actual evaporation and water surplus or runoff. The model estimates the potential evaporation using the PriestleyTaylor method. Estimation of evaporation is based upon knowledge of the potential evapotranspiration, available water-holding capacity of the soil, and a moisture extraction function. The general structure of this model is often represented as below to include the monthly time scale:

$$
S(t+1)=S(t)+P(t)-E(t)-Q(t)
$$

where $S(t)$ represents the amount of soil moisture stored at the beginning of time interval $t$; $S(t+1)$ represents the storage at the end of that interval; flow across the control surface during the interval consists of precipitation $P(t)$, actual evapotranspiration $E(t)$ and soil water surplus $Q(t)$.

The water balance model, developed to work with GIS-Arcview Avenue programs (ArcView's object-oriented programme language) interface, is being employed to estimate the water surplus (runoff) that indicates the available water resources in the basin. The study required and obtained from ftp.crwr.utexas.edu in the directory /pub/crwr/gishydro/Africa; gridded climatic dataset interpolated to a 0.5 degree grids. The climate dataset, are mean monthly values for the period of record. Generated water surpluses are excess rainfalls that are available for streamflow generation. In place of using the usual water surplus routing processes like Muskingum-Cunge method or response function approach, or the two-step flow routing approach for the transfer of the water surplus into the subwatersheds of the Niger basin, an artificial neural networks (ANNs) is being employed.

\section{ANNs model structure and weight distribution}

The neural network structure and weight distribution used in the study for the training of the networks during the calibration simulation are shown in figure 12. By definition, the regression of a dependent variable $\mathrm{y}$ on an independent variable $\mathrm{x}$, estimates the most probable value for $\mathrm{y}$, given $\mathrm{x}$ and a training set. The regression method will produce the estimated value of $y$ which minimizes the mean-squared error. The simulation is terminated when a reasonable coefficient of correlation (R), say 0.96 and above and a reasonably low value of RMSE are achieved

ANNs being an empirical and black-box model has an in-built capability that takes into consideration the watershed characteristics during simulations. The ANNs model parameters were estimated through model calibration known as the training of the networks. The network connection type is multi-layer normal feed forward, while the total number of layers is 15 , the transfer function is sigmoid and root mean square errors (RMSE) set as the objective function. The model parameters were optimized by minimizing the values of the objective function. There are number of ways of modelling or linking the relationship between the causative factor, rainfall, to runoff observed at a particular site of a basin by using equations which describe the major physical processes involved in the 
transformation or by representing these component processes in a conceptual manner, or alternatively using the neural networks approach. So considering the impossibility of representing the component processes of transformation process using a physics-based approach, one may either opt for the conceptual representation or the neural network modelling approach. While calibrating the conceptual model or the neural network model using the past recorded input with the corresponding outflows observed at a specific location of a river, it is implicit that when the calibrated model is applied for future predictions, the input that would be used in the model is in the same range of input used for the calibration. It is on this premise that a simpler approach of model-to-model calibration technique, i.e. using one model to calibrate another model, has been adopted in the study. Ninety six monthly data has been used for calibrating the ANNs and twenty four months data were used for verification. Areally averaged temperature and precipitation changes from formulated climate change synthetic scenarios were imposed on each sub-basin for assessing climate change impacts on the generated water surplus (runoff).
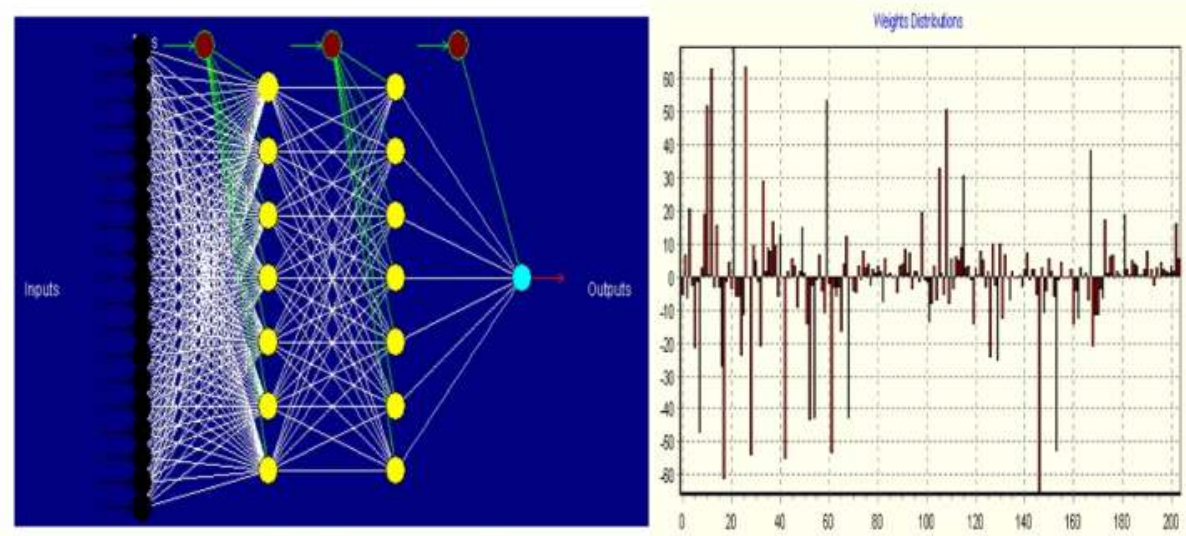

Figure 12. (a) typical architecture of the neural networks. (b) Typical weight distribution of neural networks structure

\section{Application of climate change scenarios}

Climate change scenarios are plausible indications of how future climate of a place will evolve. They are not predictions, as we know it in weather forecasting. They are generated using various global climate models (GCMs). There are three generic types of climate change scenarios: synthetic scenarios, analogue scenarios and scenarios based on output $\mathrm{s}$ from GCMs. All the three types have been used in climate change impacts research. In this study, the synthetic or hypothetical type of scenario is being applied in order to avoid the complexities of downscaling of the scenario from the outputs of GCM, which is most often used. The choice is on the premise that all the scenarios are not predictions of the future in the way that weather forecast are, but plausible indicators. Synthetic scenarios describe techniques where particular climatic (or related) elements are changed by a realistic but 
arbitrary amount, often according to a qualitative interpretation of climate model simulations for a region. Most studies have adopted synthetic scenarios of constant changes throughout the year [47] but some have introduced seasonal and spatial variations in the changes [48] and others have examined arbitrary changes in inter-annual, within-month and diurnal variability as well as changes in the mean $[49,50]$. The selected scenario will be applied in the same manner it was used by Jiang et al., 2007. The synthetic climate changes scenarios adopted in the study are shown in Table 5.

\begin{tabular}{|c|c|c|c|}
\hline Scenario no. & 1 & 2 & 3 \\
\hline$\Delta$ Temp $\left({ }^{\circ} \mathrm{C}\right)$ & 2 & 2 & 2 \\
\hline$\Delta$ Precip $(\%)$ & -20 & 0 & 20 \\
\hline
\end{tabular}

Table 5. Synthetic climate change scenario

\section{Results and discussion}

Results of analyses show discernible evidence of climatic variability and change in the Niger River basin, as adjudged by the presence of trends in the series. The practical significance of a trend is judged by a percentage change of the sample mean over an observation period. The field significance assessment demonstrates that annual temperature, precipitation, and river flow in the region show significant change as adjudged by the obtained results in Tables 6, 7, and 8. Considering the entire basin holistically and sub-basin-wise, temperature significantly increased by a value $<3.79 \%$ over the entire basin; while rainfall decreased by a value $<10.0 \%$ and river flow decreased is in the range of $14.24 \%-40.8 \%$ (Table 6). Further results show that the increasing trend in temperature is at the rate of $0.001^{\circ} \mathrm{C} / \mathrm{month}$ and $0.02^{\circ} \mathrm{C} / \mathrm{yr}$ over the entire basin. This will invariably create high evaporative demands (Fig.13), while the decreasing trend of rainfall is at the rate of $2.45 \mathrm{~mm} / \mathrm{yr}$. The increasing trends of temperature and evaporation observed over the basin are due to the global warming known to be the culprits of climate change.

This indeed is in agreement with the report of IPCC over the region [6], projected to have an increasing rate of temperature of 0.2 to $0.5^{\circ} \mathrm{C}$ per decade. As further evidence from the interactions of Niger River flows and the sub-basins rainfall in Fig 14, the whole sub-basins are highly sensitive to the climate variability and changes in the region, a decrease in runoff observed everywhere in the basin coincides with decrease in rainfall and with hardly a time lag of $>2$ years. The actual starting periods of the trends were substantiated using WMO [45] recommended 5-year average smoothening and this revealed that the present trends began since the post-civil war, economic development and population growth of 1970. These observed trends also strongly agree with that of Yue and Hashino [51], because a trend > $10 \%$ particularly in rainfall and discharge is quite significant in water resources management and planning.

The statistical significance of these trends was further explored by Thie and Sen's technique. Results obtained from this Thie and Sen approach are strongly supported by results obtained by regression test for linear trend and Kendall's Rank Correlation test (Tables 7 
and 8). This said, it is important to also assert that in some cases a well-defined rainfall trends over Upper Niger, Lower Niger and Upper Benue Sub-basins could only be established when the length of data series was increased from 60 years to a number $\geq 70$ years data. These observed hydroclimatic characteristics and trends were significant at $95 \%$ confidence level and the concomitant effect resulted in the downward trends of the river discharge over the basin, which portends danger for water resources of the region. Above results indicate the presence of change as adjudged by the trends in the series, also strongly supported by exploratory analyses shown in figures 15-17. Figures 17 and (18a and 18b) are typical of the river flow behavior at the upstream (Niger) and downstream (Nigeria). Niger River at the headwater in Niamey is obviously being threatened by the changing climate as indicated by these results and this has serious implications on the downstream flow over Nigeria. Further results characterizing the temporal climatic variability of the region reveal an increasing variability in areal temperature with coefficient of variability (CV) of $1.43 \%$ on long-term periods. The magnitude of the variability of recent time slice (1972 - 2002) was higher relative to the $1940-1971$ reference periods; with CV of $1.21 \%$ (Table 9). On the contrary, the magnitude of the temporal variability of rainfall was higher during the reference period of 1940-1971, with coefficient of variability of $8.1 \%$, even though the recent time slice (1972 - 2002) showed the greatest tendency towards aridity or drying condition, with lesser mean rainfall of $1427.8 \mathrm{~mm}$ (Table 10).

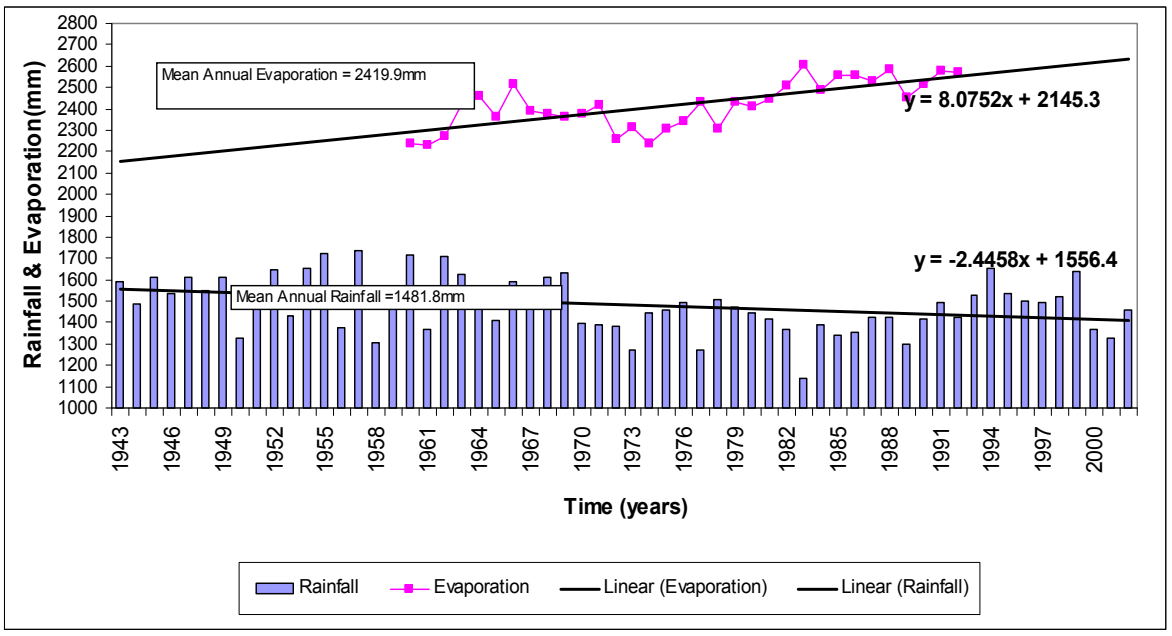

Figure 13. Annual Areal Average Rainfall and Evaporation Relationship 


\begin{tabular}{|c|c|c|c|c|}
\hline \multicolumn{5}{|c|}{ Testing the Significance of Temperature Trends Slope } \\
\hline Sub-basins & $\begin{array}{c}\text { Area Coverage } \\
\qquad\left(\mathrm{Km}^{2}\right)\end{array}$ & $\begin{array}{l}\text { Median slope } \\
\left({ }^{\circ} \mathrm{C} / \mathrm{yr}\right)\end{array}$ & $\mid \begin{array}{c}\text { Median Slope } \\
\%\end{array}$ & Remarks \\
\hline Upper Niger & 131,600 & 0.0076 & 1.3212 & Significance \\
\hline Lower Niger & 158,100 & 0.0163 & 2.9826 & Significance \\
\hline Upper Benue & 158,900 & 0.0093 & 1.6667 & Significance \\
\hline Lower Benue & 73,000 & 0.0181 & 3.2871 & Significance \\
\hline Niger South & 53,900 & 0.0171 & 3.2708 & Significance \\
\hline Entire Basin & 594,000 & 0.0169 & 3.7905 & Significance \\
\hline \multicolumn{5}{|c|}{ Testing the Significance of Rainfall Trends Slope } \\
\hline Sub-basins & $\begin{array}{c}\text { Area Coverage } \\
\left(\mathrm{Km}^{2}\right)\end{array}$ & Median Slope & M.Slope \% & Remarks \\
\hline Upper Niger & 131,600 & -3.57 & -25.19 & Significant \\
\hline Lower Niger & 158,100 & -6.01 & -4.47 & Not Significant \\
\hline Upper Benue & 158,900 & -2.22 & -5.48 & Not Significant \\
\hline Lower Benue & 73,000 & -5.65 & -16.66 & Significant \\
\hline Niger South & 53,900 & -13.89 & -12.32 & Significant \\
\hline Entire Basin & 594,000 & -2.45 & -10.00 & significant \\
\hline \multicolumn{5}{|c|}{ Testing the Significance of Niger River Flow Trends Slope } \\
\hline Stations & Area Coverage $\left(\mathrm{Km}^{2}\right)$ & Median Slope & M.Slope \% & Remarks \\
\hline $\begin{array}{l}\text { Kainji(Upper } \\
\text { Niger) }\end{array}$ & 131,600 & -3.62 & -24.72 & Significant \\
\hline $\begin{array}{l}\text { Jebba(Lower } \\
\text { Niger) }\end{array}$ & 158,100 & -438.39 & -40.80 & Significant \\
\hline $\begin{array}{l}\text { Lokoja(Lower } \\
\text { Niger) }\end{array}$ & 158,100 & -419.45 & -28.93 & Significant \\
\hline $\begin{array}{l}\text { Onitsha Niger } \\
\text { South) }\end{array}$ & 53,900 & -217.50 & -14.24 & Significant \\
\hline $\begin{array}{c}\text { Numan(Upper } \\
\text { benue) }\end{array}$ & 158,900 & -319.68 & -31.10 & Significant \\
\hline $\begin{array}{c}\text { Makurdi(Lower } \\
\text { Benue) }\end{array}$ & 73,000 & -258.75 & -27.85 & Significant \\
\hline
\end{tabular}

Table 6. THIE AND SEN'S Median Slope Computation 


\begin{tabular}{|c|c|c|c|c|c|c|}
\hline Station & Slope & Variance & T-Statistics & t-Test & Error & $\begin{array}{l}\text { Nature of Trend } \\
\text { at } 5 \% \text { Sig. Level }\end{array}$ \\
\hline Upper Niger & 0.0087 & 0.00000635 & 3.4514 & 2.001 & 0.002519 & Positive Trend \\
\hline Lower Niger & 0.0170 & 0.00000419 & 8.3190 & 2.001 & 0.002047 & Positive Trend \\
\hline Niger South & 0.0179 & 0.00000388 & 9.0740 & 2.001 & 0.001972 & Positive Trend \\
\hline Upper Benue & 0.0097 & 0.00000822 & 3.3708 & 2.001 & 0.002867 & Positive Trend \\
\hline Lower Benue & 0.0197 & 0.00000739 & 7.2478 & 2.001 & 0.002719 & Positive Trend \\
\hline Entire Basin & 0.0172 & 0.00000364 & 9.0271 & 2.001 & 0.00191 & Positive Trend \\
\hline \multicolumn{7}{|c|}{ a } \\
\hline Station & Slope & Variance & T-Statistics & $\mathrm{t}$-Test & Error & $\begin{array}{l}\text { Nature of Trend } \\
\text { at } 5 \% \text { Sig. Level }\end{array}$ \\
\hline Upper Niger & -1.904 & 0.695 & -2.284 & 2.003 & 0.834 & Negative Trend \\
\hline Lower Niger & -10.01 & 13.088 & -2.775 & 2.003 & 3.617 & Negative Trend \\
\hline Niger South & -11.837 & 21.453 & -2.56 & 2.003 & 4.632 & Negative Trend \\
\hline Upper Benue & -6.640 & 4.745 & -3.048 & 2.003 & 2.178 & Negative Trend \\
\hline Lower Benue & -8.564 & 10.136 & -2.690 & 2.003 & 3.184 & Negative Trend \\
\hline Entire Basin & -2.446 & 0.8377 & -2.672 & 2.003 & 0.915 & Negative Trend \\
\hline
\end{tabular}

Table 7. a: Results of Regression Test for Linear Trend of Temperature over Niger River Basin b: Results of Regression Test for Linear Trend of Rainfall over Niger River Basin

\begin{tabular}{|c|c|c|c|c|c|c|}
\hline Station & $\begin{array}{c}\text { Test } \\
\text { Statistics }\end{array}$ & P-Values & Trend & $\begin{array}{c}\text { Year Trend } \\
\text { Begins }\end{array}$ & Nature of Trend & $\begin{array}{c}\text { Warmest Year of } \\
\text { Period \& value }\end{array}$ \\
\hline $\begin{array}{c}\text { Upper } \\
\text { Niger }\end{array}$ & 6.569 & 1400 & Positive & 1972 & $\begin{array}{c}\text { Sig. between } 1 \text { and } \\
5 \% \text { Sig. Level }\end{array}$ & $1987\left(2.45^{\circ} \mathrm{C}\right)$ \\
\hline $\begin{array}{c}\text { Lower } \\
\text { Niger }\end{array}$ & 5.868 & 1345 & Positive & 1979 & $\begin{array}{c}\text { Sig. between } 1 \text { and } \\
\text { 5\% Sig. Level }\end{array}$ & $1987\left(3.0^{\circ} \mathrm{C}\right)$ \\
\hline $\begin{array}{c}\text { Niger } \\
\text { South }\end{array}$ & 7.233 & 1246 & Positive & 1973 & $\begin{array}{c}\text { Sig. between } 1 \text { and } \\
\text { 5\% Sig. Level }\end{array}$ & $1998\left(2.54^{\circ} \mathrm{C}\right)$ \\
\hline $\begin{array}{l}\text { Upper } \\
\text { Benue }\end{array}$ & 4.605 & 1452 & Positive & 1979 & $\begin{array}{c}\text { Sig. between } 1 \text { and } \\
\text { 5\% Sig. Level }\end{array}$ & $2002\left(2.81^{\circ} \mathrm{C}\right)$ \\
\hline $\begin{array}{l}\text { Lower } \\
\text { Benue }\end{array}$ & 6.163 & 1167 & Positive & 1979 & $\begin{array}{c}\text { Sig. between } 1 \text { and } \\
5 \% \text { Sig. Level }\end{array}$ & $1998\left(2.53^{\circ} \mathrm{C}\right)$ \\
\hline $\begin{array}{l}\text { Entire } \\
\text { Basin }\end{array}$ & 6.722 & 1412 & Positive & 1979 & $\begin{array}{c}\text { Sig. between } 1 \text { and } \\
5 \% \text { Sig. Level }\end{array}$ & $1998\left(2.6^{\circ} \mathrm{C}\right)$ \\
\hline \multicolumn{7}{|c|}{} \\
\hline
\end{tabular}


Climate Change - Realities, Impacts Over Ice Cap, Sea Level and Risks

\begin{tabular}{|l|l|l|l|l|l|}
\hline Station & $\begin{array}{l}\text { Test- } \\
\text { Statistic }\end{array}$ & $\begin{array}{l}\text { P- } \\
\text { Value } \\
\text { s }\end{array}$ & Trend & $\begin{array}{l}\text { Year } \\
\text { Trend } \\
\text { Begins }\end{array}$ & Nature of Trend \\
\hline $\begin{array}{l}\text { Upper } \\
\text { Niger }\end{array}$ & -2.755 & 963 & Negative & 1970 & Sig. between 1 and 5\% Sig. Level \\
\hline $\begin{array}{l}\text { Lower } \\
\text { Niger }\end{array}$ & -3.261 & 914 & Negative & 1982 & Sig. between 1 and 5\% Sig. Level \\
\hline $\begin{array}{l}\text { Niger } \\
\text { South }\end{array}$ & -2.80 & 715 & Negative & 1972 & Sig. between 1 and 5\% Sig. Level \\
\hline $\begin{array}{l}\text { Upper } \\
\text { Benue }\end{array}$ & -1.962 & 1173 & Negative & 1967 & Sig. at 5\% Sig. Level \\
\hline $\begin{array}{l}\text { Lower } \\
\text { Benue }\end{array}$ & -2.375 & 750 & Negative & 1973 & Sig. at 5\% Sig. Level \\
\hline
\end{tabular}

Table 8. a: Results of Kendall's Rank Correlation Test of Temperature over Niger Basin b: Results of Kendall's Rank Correlation Test of Rainfall over Niger River Basin

\begin{tabular}{|c||c|c|c|c|c|c|c|c|c|c|}
\hline Period & Mean & $\begin{array}{c}\text { Std. } \\
\text { Dev. }\end{array}$ & CV (\%) & Max & Year & Min & Year & $\begin{array}{c}\text { Max as \% } \\
\text { of Ave. }\end{array}$ & $\begin{array}{c}\text { Min as \% of } \\
\text { Ave. }\end{array}$ \\
\hline \multicolumn{8}{|c|}{ Long-term Period } \\
\hline $1943-2002$ & 319.60 & 4.58 & 1.43 & 330.70 & $1987 / 88$ & 312.52 & $1961 / 62$ & 103.47 & 97.78 \\
\hline \multicolumn{8}{|c|}{ Reference Periods } \\
\hline $1943-1971$ & 316.39 & 2.75 & 0.87 & 327.22 & $1972 / 73$ & 312.52 & $1961 / 62$ & 103.42 & 98.78 \\
\hline $1972-2002$ & 322.60 & 3.87 & 1.20 & 330.70 & $1987 / 88$ & 315.81 & $1974 / 75$ & 102.51 & 97.9 \\
\hline
\end{tabular}

Table 9. Temporal Areal Temperature Variability over Niger River Basin in Nigeria

\begin{tabular}{|c|c|c|c|c|c|c|c|c|c|}
\hline Period & Mean & Std. Dev. & CV $(\%)$ & Max & Year & Min & Year & $\begin{array}{c}\text { Max as \% } \\
\text { of Ave. }\end{array}$ & $\begin{array}{c}\text { Min as } \% \text { of } \\
\text { Ave. }\end{array}$ \\
\hline \multicolumn{10}{|c|}{ Long-term Period } \\
\hline $\begin{array}{c}1943- \\
2002\end{array}$ & $\begin{array}{c}1481 . \\
8\end{array}$ & 128.01 & 8.64 & 1738.6 & $1957 / 58$ & 1139.7 & $1983 / 84$ & 117.33 & 76.91 \\
\hline \multicolumn{10}{|c|}{ Reference Periods } \\
\hline $\begin{array}{c}1943- \\
1971\end{array}$ & $\begin{array}{c}1539 . \\
6 \\
\end{array}$ & 125.26 & 8.14 & 1738.6 & $1957 / 58$ & 1303.2 & $1958 / 59$ & 112.92 & 84.65 \\
\hline $\begin{array}{l}1972- \\
2002\end{array}$ & $\begin{array}{c}1427 \\
8\end{array}$ & 106.48 & 7.46 & 1656.0 & $1994 / 95$ & 1139.7 & $1983 / 84$ & 115.99 & 79.82 \\
\hline
\end{tabular}

Table 10. Temporal Areal Rainfall Variability over Niger River Basin in Nigeria 

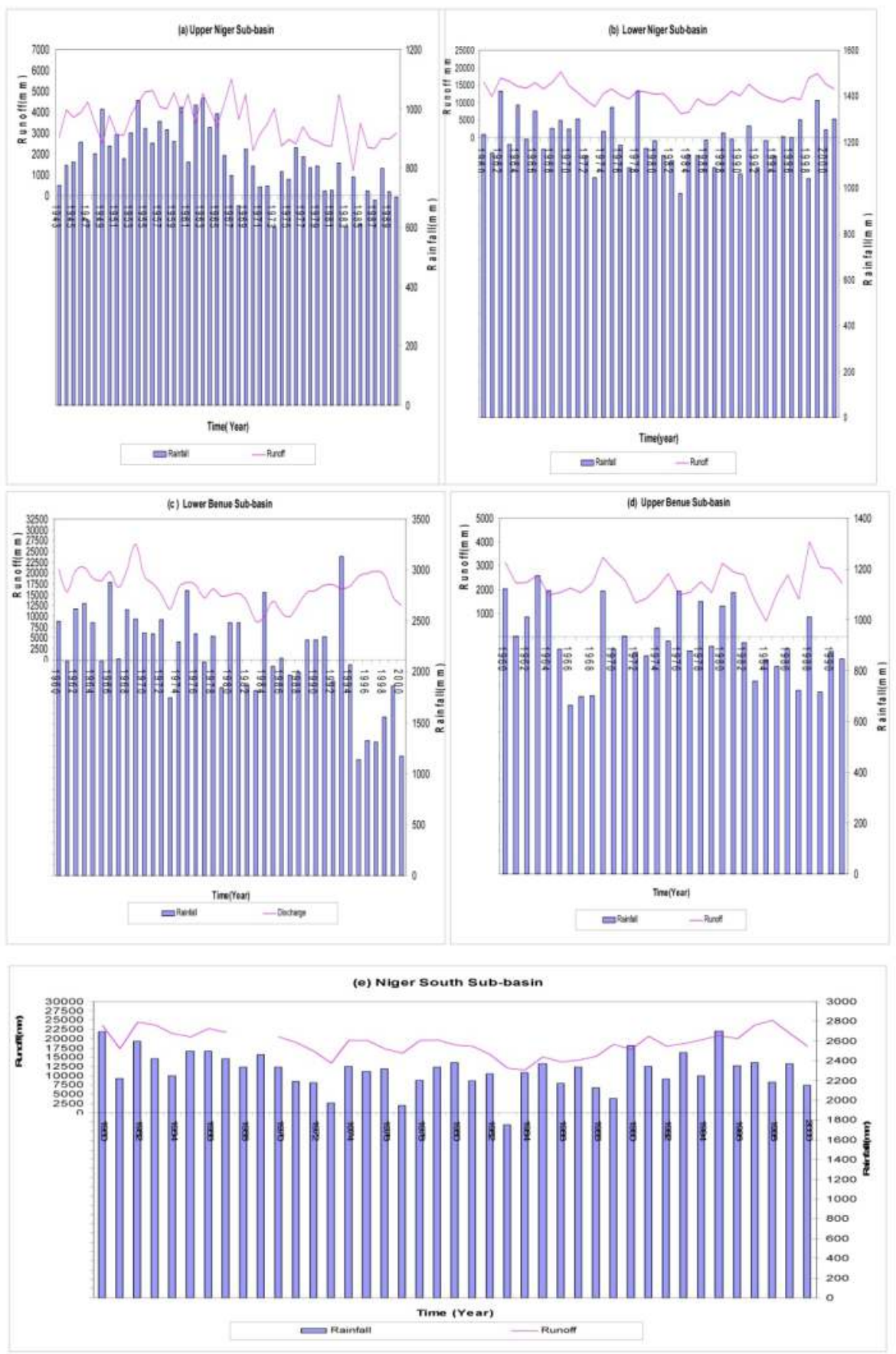

Figure 14. River Flows Interactions with Sub-basins Rainfall 


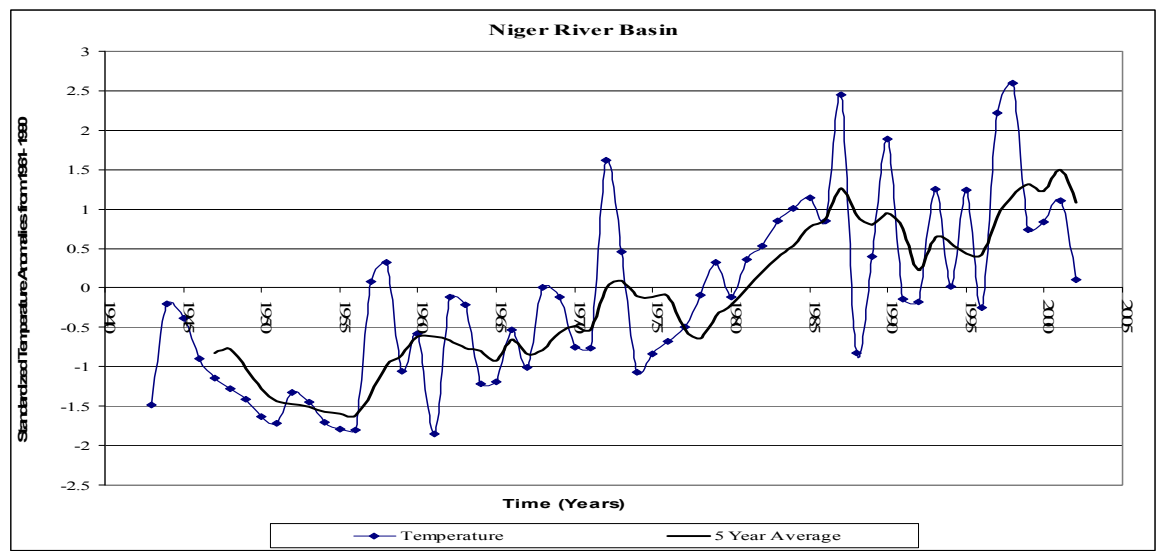

Figure 15. Standardized Annual Areal Average Temperature Variability and Trend

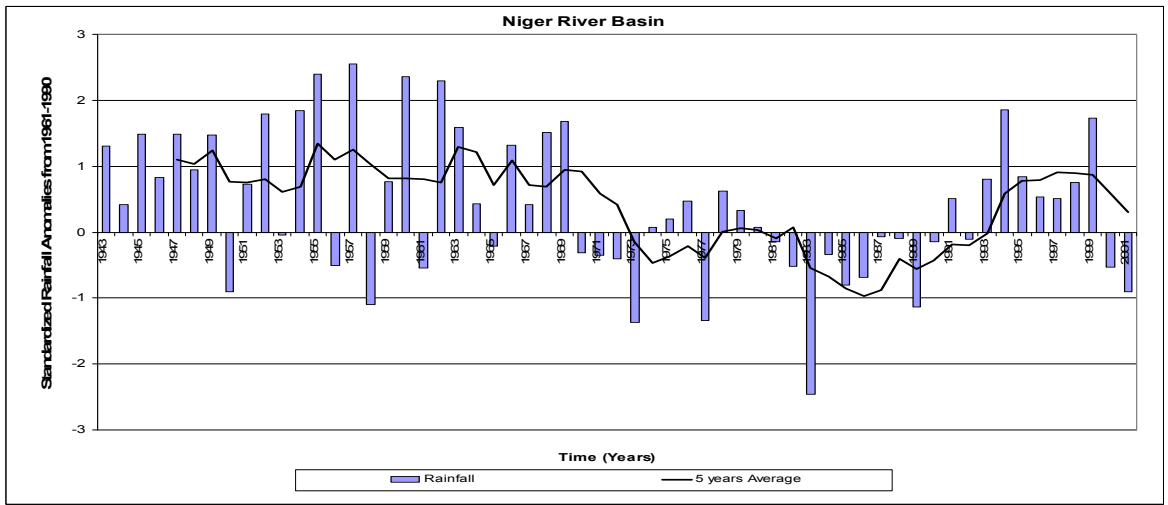

Figure 16. Standardized Annual Areal Average Rainfall Variability and Trend

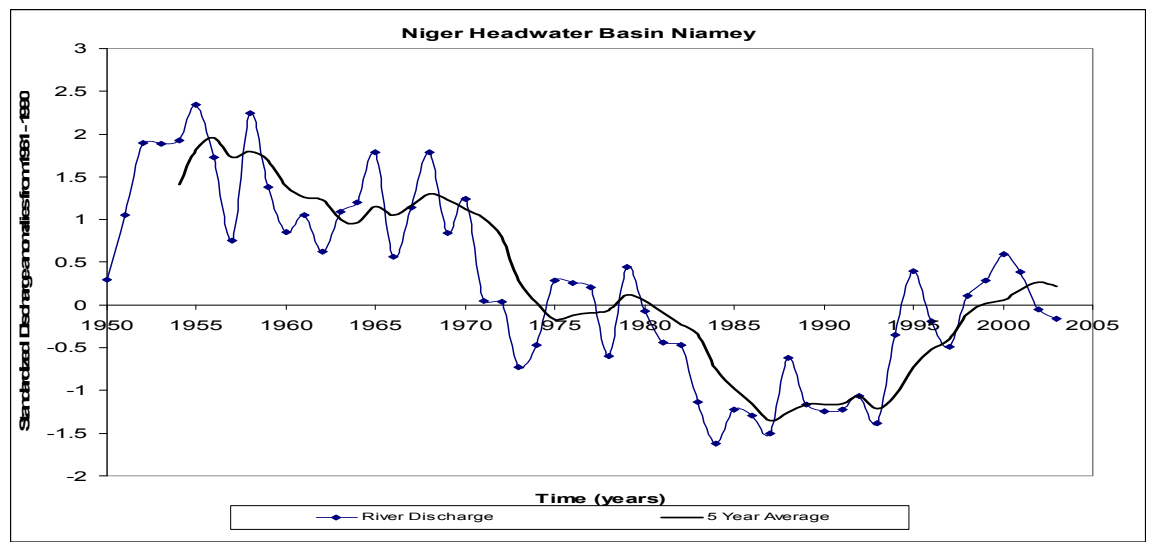

Figure 17. Typical Temporal Variability and Trend of Niger River over Niamey (Headwater Basin) 


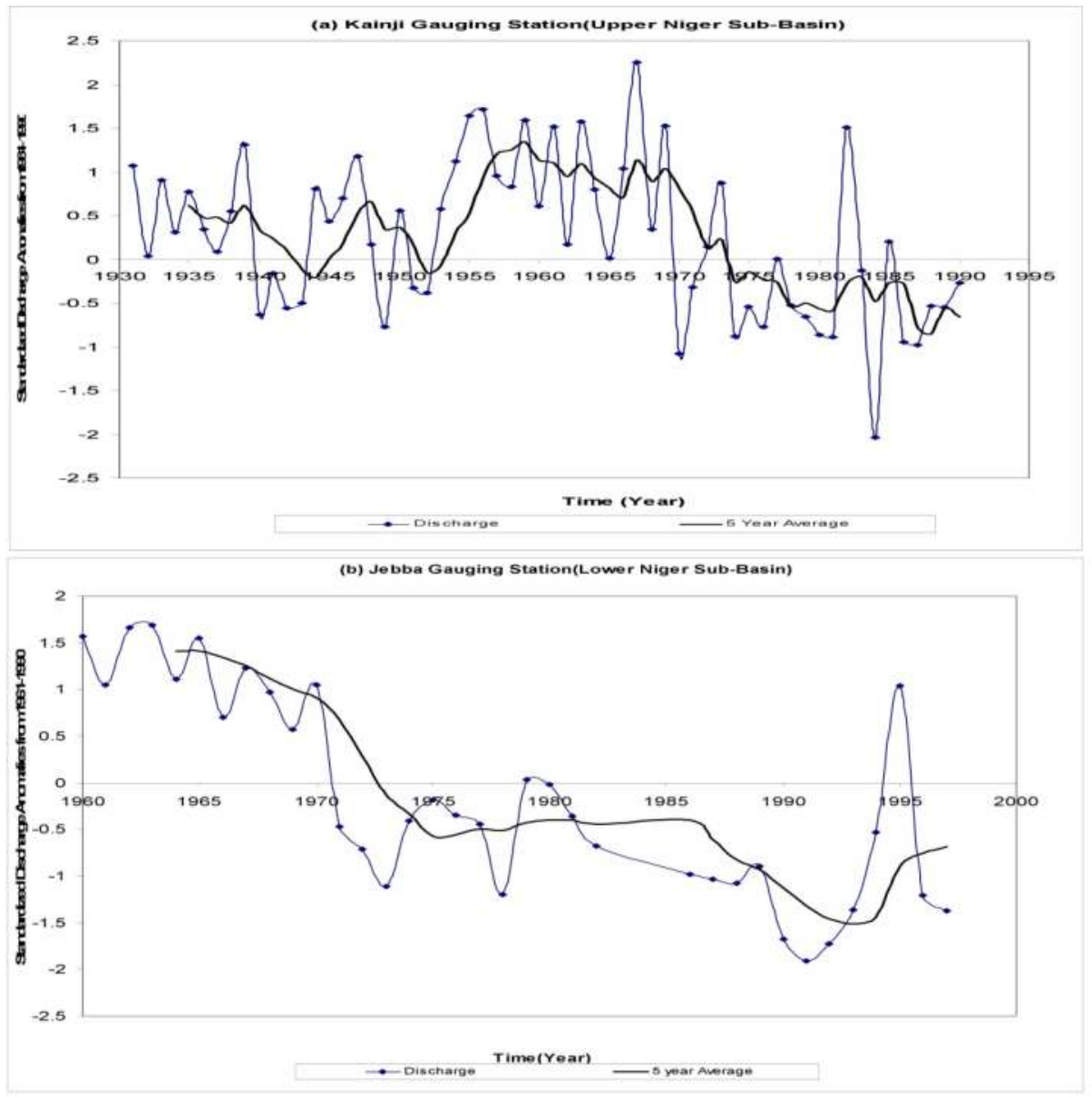

Figure 18. Typical Temporal Variability and Trends of annual River Flow over the Niger Sub-basins

\subsection{Future climate change in the Niger River Basin}

Although, there are no consensus among the Global Climate Models(GCMs) on whether the West African region will become drier or wetter over the course of the $21^{\text {st }}$ century, because half of the 21 GCMs used by IPCC predict increased rainfall, while the remaining half predict decreased rainfall [1]. But most of the models do agree that climatic variability will increase over the region. Subsequently, climate change is expected to have a key influence not only on water resources, but on food and human security through its impacts on climate variability and extremes. Again, it is important to state that major portion of the Niger River basin located outside the Sahelian region lies within the humid tropical zone of southern Nigeria; a region already experiencing high temperature, evapotranspiration and rainfall. While climate models differ however, modeling done in this study reveals the high level of 
varying sensitivity of the Niger River basin, particularly the lower Niger sub-basin to the changing climate, which justifies the various experiences of impacts of climate change in the region. Results show direct link between rainfall and runoff (water surplus) generated over the Niger River basin. The peak of the rainfall coincides with the same month as the peak of water surplus and vice versa (Fig. 19). Since water surplus indicates the available water resources of the region, this reveals how sensitive the available water resources are to the climate of the region. Over the Upper Niger sub-basin, a peak rainfall of $265 \mathrm{~mm}$ in the month of August, produced a runoff or water surplus of $160.5 \mathrm{~mm}$; while over Lower Niger and Niger South sub-basins, peak rainfall of $294 \mathrm{~mm}$ and $347 \mathrm{~mm}$ yielded water surplus of $185 \mathrm{~mm}$ and $238 \mathrm{~mm}$, respectively. The annual water surplus or runoff was highest over the Niger south $(1241.2 \mathrm{~mm})$ closer to Atlantic ocean, followed by Lower Benue (973.6mm), Lower Niger $(729.4 \mathrm{~mm})$, Upper Benue $(495.3 \mathrm{~mm})$ sub-basins and the least value is observed over Upper Niger Sub-basin $(360.7 \mathrm{~mm})$ in the Sudano-Sahel zone. It is further observed that the water surplus is much more sensitive to the accuracy of potential evaporation estimate (that depends on temperature) in the humid climate than the arid climate.

The calibration and optimization results show that the models performance has been quite good, as adjudged by the values of RMSE and Nash Sutcliff Efficiency (E). Generic example of such outcomes are Upper Niger (12.6909 /and 0.9362), Lower Niger (8. 4665 and 0.9578) and Niger South (4.1315 and 0.9987). The highest RMSE values and lowest $E$ values were observed over Niger South and Lower Niger sub-basins respectively.

Figure 20 is the visual output of the calibration simulation of the ANNs. It suffices to say from the result that the models have shown good capabilities to reproduce historical monthly runoff series with an acceptable accuracy proved by verification results (Figs. 20). However, the necessary assumptions made and the absence of intermediate component processes of rainfall- runoff transformation should be kept in mind; hence estimated observed values obtained through ANNs model has been used in place of actual observed runoff for the water balance calibration. Therefore, there may be need to further verify these results with actual field data.

Additionally, in order to evaluate the seasonal and inter-annual changes, differences in mean monthly runoff simulated by the ANNs using the climate change scenarios were compared with a baseline runoff values. Results show various changes in runoff expected over the Niger basin in the face of the projected climate change (fig. 21). It is further observed that when temperature increases by $2^{\circ} \mathrm{C}$, the mean monthly runoff on the average changed by -10 to $-50 \%,-5$ to $-40 \%$ and 15 to $60 \%$ respectively for precipitation changes of $20 \%, 0 \%$ and $20 \%$ (Table 11). Hence, if the current prevailing climatic conditions of increasing temperature trend and decreasing rainfall trends continue unabatedly, projected climate change may exacerbate its impacts on the water resources of the region, resulting in water stress condition. By implications then, freshwater, hydro-power, health and food security of the country may be seriously threatened, unless rainfalls turnout to be on the increase and adequate management strategy put in place. 

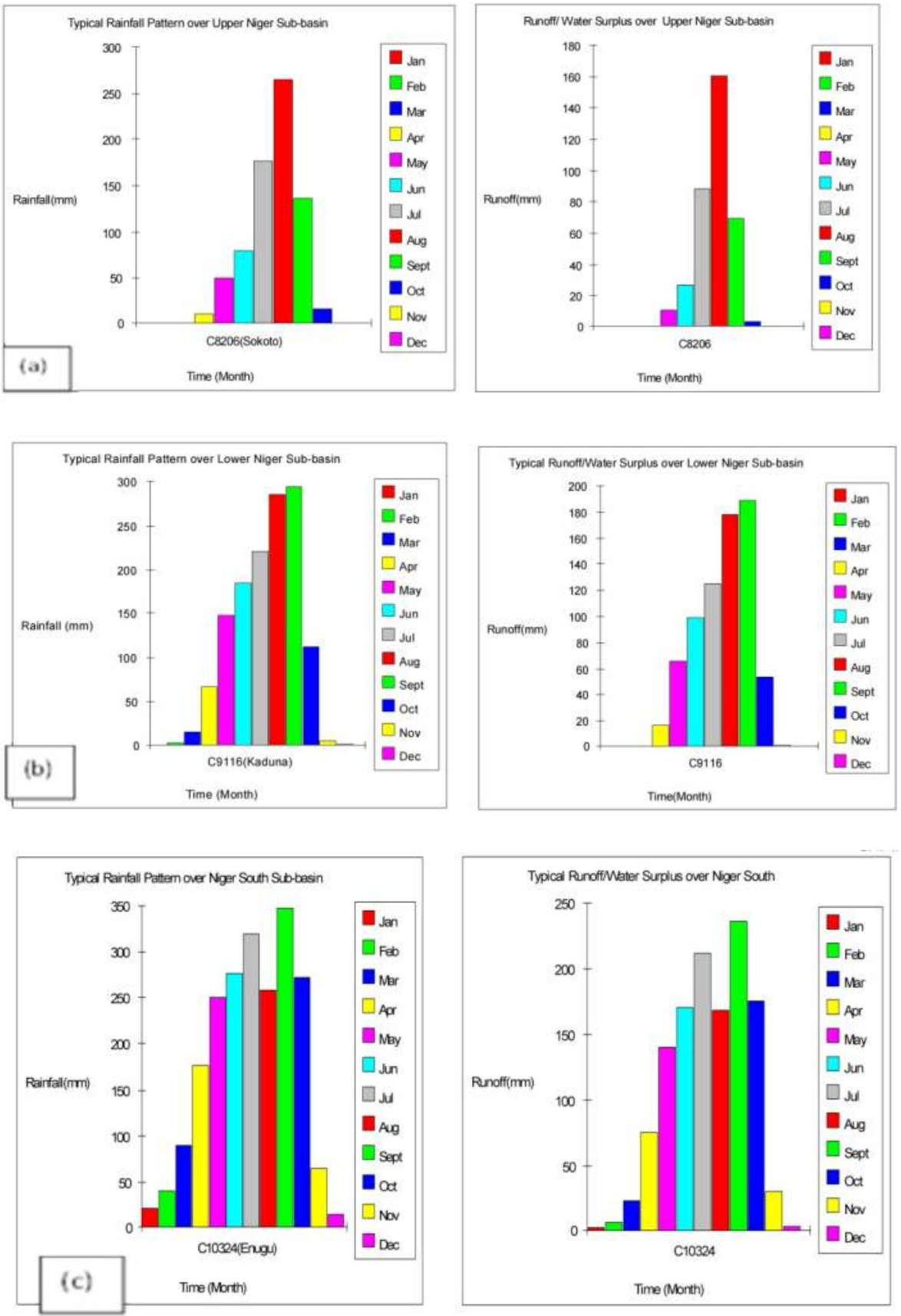

Figure 19. Typical Simulated Runoff and Climatic Conditions over (a) Upper Niger Basin (b) lower Niger and(c) Niger south sub-basins 

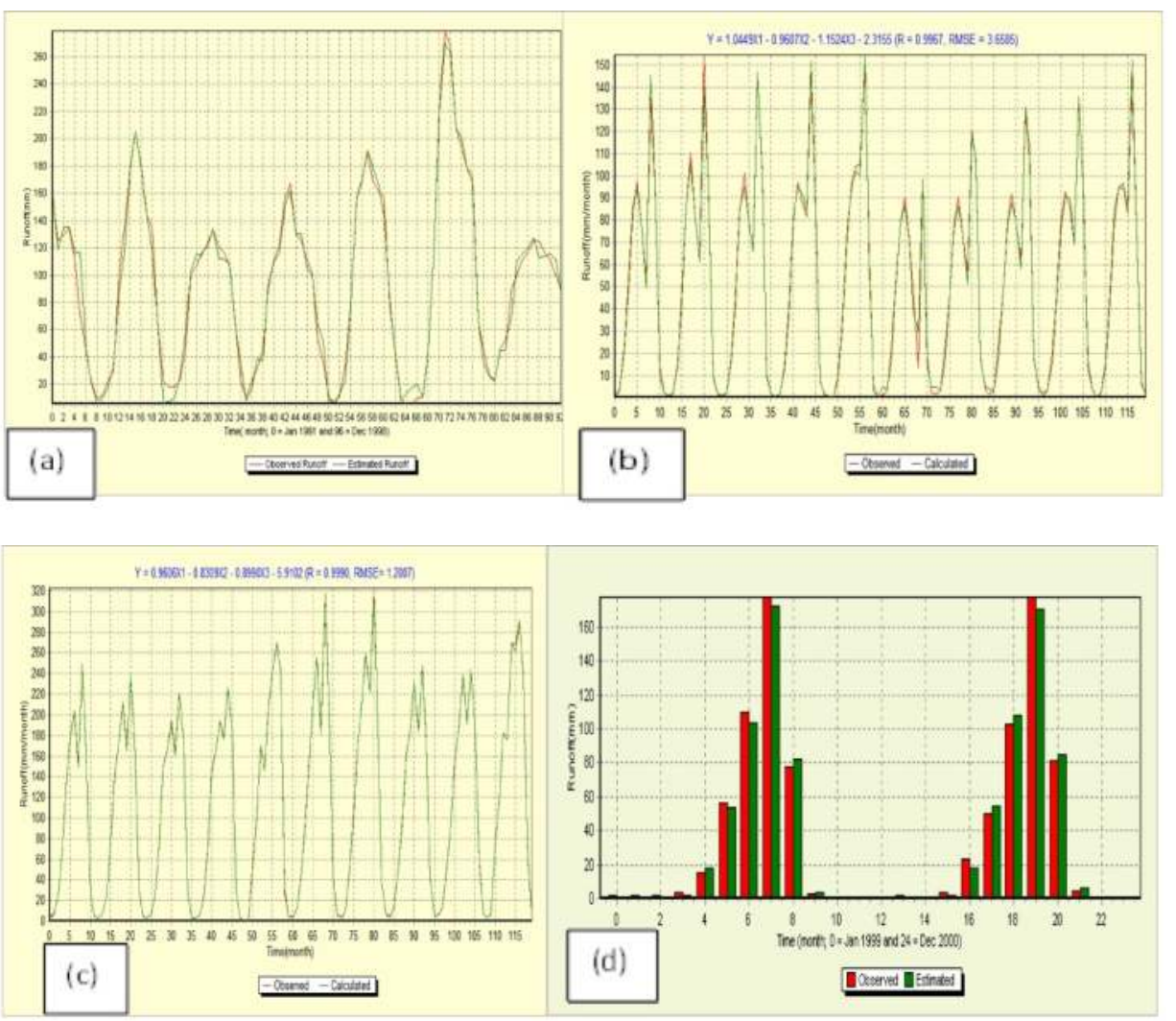

Figure 20. Typical ANNs Model Calibration Simulation Output over (a) Upper Niger (b) Lower Niger (c) Niger South Sub- basins and (d) model verification output (Upper Niger) 

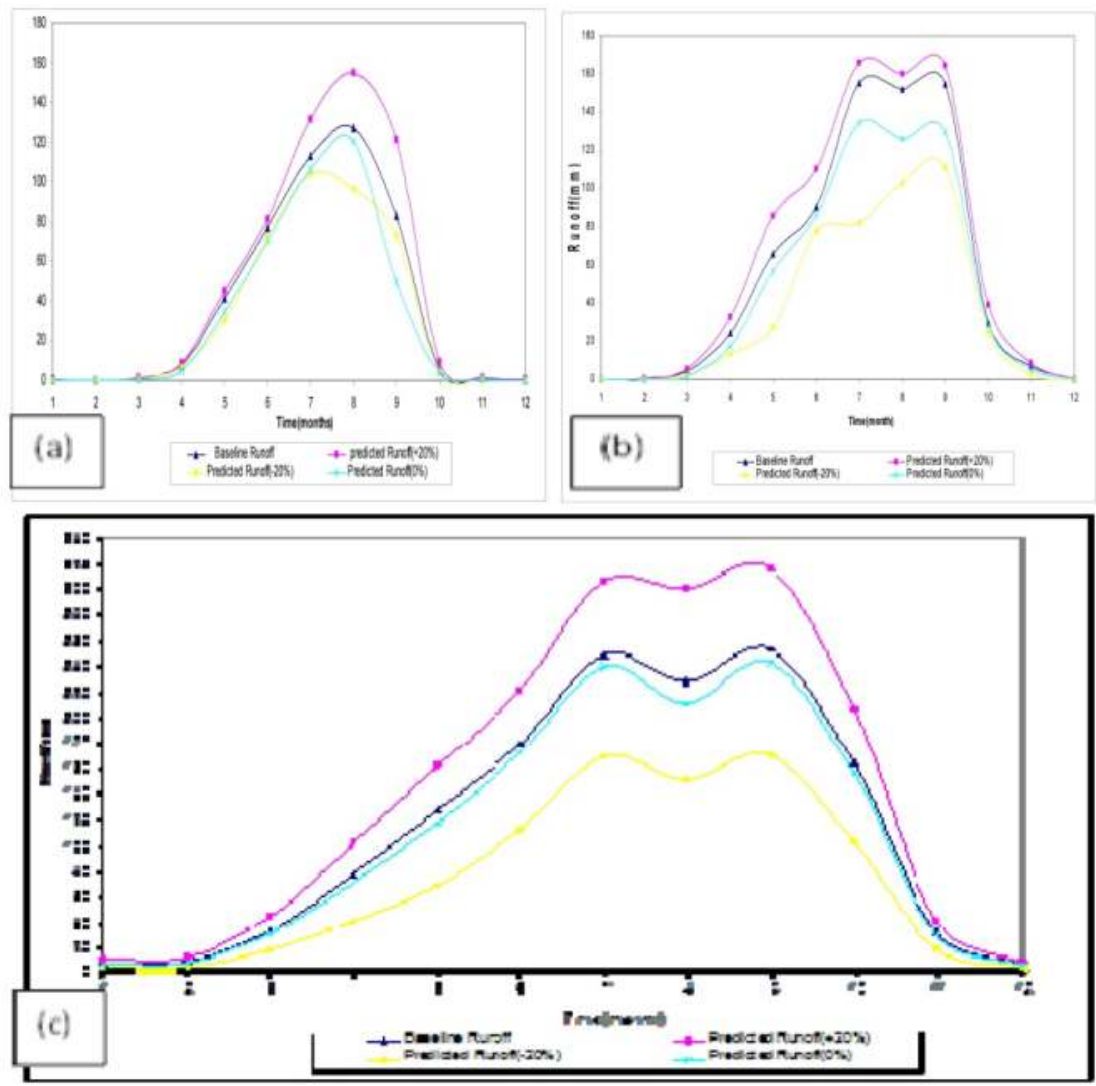

Figure 21. Typical Changes in Runoff under Climate Change Scenarios of Temperature $=+2^{\circ} \mathrm{C}$ and Precipitation $=+20 \%$ and $0 \%$ over (a) Upper Niger,( b) Lower Niger and (c)Niger South Sub-basins

\section{Conclusion}

This study explored and assessed the potential impacts of projected climate change on water resources of Nigerian sector of Niger River basin using both parametric and non-parametric approaches and simulation models i.e. Thornthwaite water balance accounting scheme and Artificial neural networks (ANNs). There is discernible evidence of climate change in Nigeria, adjudged by the observed changes in the in the onset and cessation dates of seasonal rains and the presence of trends in the hydo-climatic series. It is further observed that apart from the Sahel region, Sudano-Guinean region or the humid portion in the lower Niger sub-basin are also vulnerable to the changing climate and its impacts. The observed changes are not unlikely to be connected to the long time variability in the climatic variables of the region, and land use changes due to increasing anthropogenic activities and gas flaring and population pressure. Also, a future drier climate is expected to impact negatively on the runoff and invariably on the available water resources of the region. Hence, proactive 
and aggressive management strategy is seriously needed to match any unfathomable impact.

\section{Author details}

Juddy. N. Okpara and Aondover. A.Tarhule

Department of Geography and Environmental Sustainability, University of Oklahoma, Norman, USA

Muthiah Perumal

Department of Hydrology, Indian Institute of Technology, Roorkee, India

\section{Acknowledgement}

The greatest acknowledgement goes to God Almighty, the author and finisher of our life for the inspiration and wisdom to put this piece of work together. We are also grateful to Professor Maidment and his team and the University of Texas for making available the GISArcView avenue script used for the modeling, as well as the gridded data.

\section{References}

[1] Christensen, J.H., Hewitson, B., Busuioc, A., Chen, A., Gao, X., Held, I., Jones, R., Kiolli, R.K., Kwon, W.-T., Laprise, R., Magaña Rueda, V., Mearns, L., Menéndez, C.G., Räisänen, J., Rinke, A., Sarr, A. and Whetton, P. (2007). 'Regional climate projections' in Solomon, S., Qin, D., Manning, M., Chen, Z., Marquis, M., Averyt, K.B., Tignor, M. and Miller, H.L. (Eds.) Climate Change 2007: The Physical Science Basis. Contribution of Working Group I to the Fourth Assessment Report of the Intergovernmental Panel on Climate Change. Cambridge, UK and New York, US: Cambridge University Press.

[2] Oyebande L. ,Amani A., Mahe G., Diop I. N.(2002) Climate change, water and wetlands in West Africa: Building linkages for their integrated Management.Special Comminssioned paper. IUCN-BRAO. Ouagadougou, April, 2002

[3] Niasse, M., Afouda, A. and Amani, A. (2004) Reducing West Africa's Vulnerability to Climate impacts on water resources, wetlands and desertification: Elements for a Regional Strategy for preparedness and Adaptatio. International Union for Conservation of Nature and Resources (IUCN), Cambridge, $84 \mathrm{pp}$

[4] Watson, R.T. (Ed.) (2001). Climate Change 2001: Synthesis Report, Contribution of Working Groups I, II and III to the Third Assessment Report of the Intergovernmental Panel on Climate Change. Published for the Intergovernmental Panel on Climate Change. Cambridge: Cambridge University Press. Available at http:// www.ipcc.ch/pdf/climate-changes-2001/synthesis-syr/english/front.pdf (79Kb).

[5] Conway, D., Persechino, A., Ardoin-Bardin, S., Hamandawana, H., Dieulin, C. and Mahe, G. (2009). 'Rainfall and river flow variability in Sub-Saharan Africa during the twentieth century', Journal of Hydrometeorology, Vol. 10, pp. 41-59. 
[6] IPCC (2007): Summary for policy-makers. In: Climate Change 2007: The physical Science Basis. Contributions of Working Group I to the Forth Assessment Report of the Intergovernmental Panel on Climate Change.

[7] Hulme, M. (2001). 'Climatic perspectives on Sahelian desiccation: 1973-1998', Global Environmental Change, Vol. 11, pp. 19-29.

[8] Camberlin, P. and Diop, M. (2003): Application of Rainfall principal Component Analysis to the assessment of rainy season characteristics in Senegal

[9] Giannini, A., Saravanan, R. and Chang, P. (2003). 'Oceanic forcing of Sahel rainfall on interannual to interdecadal timescales', Science, Vol. 302, pp. 1027-1030.

[10] Dai A., Lamb, P.J., Trenberth, K.E., Hulme, M., Jones, P.D. and Xie, P.( 2004) The recent Sahel drought is real. Int. J. Climatol., 24, 1323-1331

[11] Okorie, F.C. 2003. Studies on Drought in the sub- Saharan Region of Nigeria using remote sensingand precipitation data, JNCASR- Costed Fellowship Programme, University of Hyderabad, India,January- April.

[12] Olaniran, O. J. (1991). Evidence of climatic change in Nigeria based on annual rainfall series 1919-1985. Climate Change, 19, 507-520. doi:10.1007/BF00140169, http://dx.doi.org/10.1007/BF00140169

[13] Hulme, M. (1992): Rainfall Changes in Africa: 1931-1960 to 1961-1990, Int. J. Climatology 12:685-699

[14] Anyadike, R. (1993) Seasonal and annual rainfall variations over Sudan. International Journal of Climatology, 13, 567-580.

[15] Mah'e G, Paturel JE, Servat E, Conway D, Dezetter A. 2005. Impact of land use change on soil water holding capacity and river modelling of the Nakambe River in BurkinaFaso. Journal of Hydrology 300: 33-43.

[16] Grolle, J. (1997) Heavy rainfall, famine, and cultural response in the West African Sahel: the "Muda" of 1953-54', GeoJournal, Vol. 43, No. 3, pp. 205-214.

[17] Goulden, M. and Few, R.( 2011) Climate Change, Water and Conflict in the Niger River Basin, USAID, Reliefweb report-http://reliefweb, int/node/474471

[18] Cook, S., Fisher, M., Tiemann, T. and Vidal, A. (2011). 'Water, food and poverty: Globaland basin-scale analysis', Water International, Vol. 36, pp. 1-16.

[19] Paeth, H., Fink, A. and Samimi, C. (2009). 'The 2007 flood in sub-Saharan Africa: Spatiotemporalcharacteristics, potential causes, and future perspective', EMS Annual Meeting Abstracts, Vol. 6, EMS2009-103.

[20] Tarhule, A. (2005). 'Damaging rainfall and flooding: The other Sahel hazards', Climatic Change, Vol. 72, pp. 355-377.

[21] Oyebande, L.(1995):Global Climate Change and Sustainable Water Management for Energy production in the Niger Basin of Nigeria: Proceedings of Global Climate Change: Impact on energy development conference, 1995( ed. Engr J.C. Umolu P.E. and published by DAMTECH Nigeria Limited Anglo-Jos, Plateau State, Nigeria). 
[22] Milly, P.C.D.,Betancourt, J. Falkenmark, Hirsch, R. M. Kundzewich Z.W. Lettenmaier, D.P. and Scouffer,R.J. (2008) Stationarity is dead: Whither water management? Science Vol.319, $1^{\text {st }}$ February, 2008, Pp 573-574

[23] Oyebande, L. and Odunuga, S. ( 2010) Climate Change on water resources at the Transboundary level in West Africa: The cases of the Senegal, Niger and Volta basins, The open Hydrology journal, 2010, 4,163-172

[24] Olomoda, I. A. (2004): Impact of climatic change on river Niger hydrology. Proceedings of International Workshop on Managing Shared Aquifers Resources in Africa, held in Tripoli Libya, 2nd to 4th June 2002, pgs 190-197

[25] Dessouassi, R. (2000). Revue des perspectives dans le Bassin du fleuve Niger, $A B N$, Niger. Instititut National de la Statistique: INS, Niamey, Niger, 2010.

[26] Ogilvie, A., Mahe G., Ward, J., Serpantie, G., Lemoalle, J.,Morand, P. Barbier, B., Diop, A.T., Caron, A., Namarra, R., Kaczan D., Lukasiewicz, A., Paturel, J.E., Lienou, G. and Clanet, J. C.( 2010) Water, agriculture and poverty in the Niger River basin, Water International vol. 35, No. 5, September, 2010, 549-622

[27] Descroix, L.,G. Mahé, T. Lebel,G. Favreau, S. Galle, E. Gautier, J.C. Olivry, J. Albergel,O. Amogu,B. Cappelaere,R. Dessouassi,A. Diedhiou, E. Le Breton, I. Mamadou, D. Sighomnou (2009). Spatio-Temporal variability of hydrological regimes around the boundaries between Sahelian and Sudanian

[28] Salami, A.T. and Akinyede, J. (2006).: Space technology for monitoring and managing forest in Nigeria, a paper presented at the International Symposium on Space and Forests, United Nations Committee on Peaceful Uses of Outer Space (UNOOSA), Vienna, Austria.

[29] Agbola, T. and Olurin, T. A. (2003): Landuse and Landcover Change in the Niger Delta. Excerpts from a Research Report presented to the Centre for Democracy and Development, July, 2003

[30] Awosika, L. F. (1995). Impacts of global climate change and sea level rise on coastal resources and energy development in Nigeria. In: Umolu, J. C. (ed). Global Climate Change: Impact on Energy Development. DAMTECH Nigeria Limited, Nigeria

[31] Casenave L. (2004) Hydro-climatic variability: comparison of different global circulation model in western Africa. Master thesis. University of Chalmers, Sweden. 52 p.

[32] Nicholson, S.E. (2000) Land surface processes and Sahel climate', Reviews of Geophysics, Vol. 38, No. 1, pp. 117-139.

[33] Taylor, R. G. and Howard, K.W.F. (1996) Groundwater recharge in the Victoria Nile basin of East Africa: Support for the soil-moisture balance method using stable isotope and flow modeling studies. Journal of Hydrology, 180, 31-53

[34] Hulme, M. (1992) Rainfall Changes in Africa: 1931-1960 to 1961-1990, Int. J. Climatology 12:685-699.

[35] Nicholson, S. E. (1993) An overview of African rainfall fluctuations of the last decades, Journal of climate, vol. 6 1463-1466 
[36] Gbuyiro, S. O. \& Aisiokuebo, N (2003) Climate change in Nigeria-Its reality, expectations and impacts. In: Proc. International Symposium on Climate Change (March-April, 2003, China), 238-240. WMO/TD No. 1172.

[37] Okpara J.N., Akeh, L.E. and Anuforom, A. C. (2006): Possible impacts of Climate Variability/ change and urbanization on water resources of availability and quality in the Benin-Owena River Basin IAHS Publication 308, ISSN 0144 - 7815, pg 394 400.

[38] Okpara, J. N. (2007): Monitoring the impacts of Climate Change/ Variability and Anthropogenic Activities on Lake Chad, Northeastern Nigeria, Using remote Sensing Satellite, Proceedings of IUGG2007 International Conference, Perugia, Italy.

[39] FAO (Food and Agriculture Organization) (1997). Irrigation potential in Africa: A basin approach, Land and Water Bulletin 4. Rome: Food and Agriculture Organization of the United Nations. Available at http://www. fao.org/docrep/W4347E/w4347e00.htm\#Contents.

[40] Andersen, I., Dione, O., Jarosewich-Holder, M. and Olivry, J-C. (2005). The Niger River Basin: A vision for sustainable management. Washington DC, US: The World Bank.

[41] MahooH.F., Young, M.D.B., and Mzirai, O. B. (1999)Rainfall variability and its implications for the transferability of experimental results in semi-arid areas of Tanzania. Tanzania Journal of Agricultural Science 2(2) 127-140

[42] Keay, R.W.J., 1959. An Outline of Nigerian Vegetation. Lagos

[43] White, F. (1983) The vegetation of Africa, a descriptive memoir to accompany the UNESCO / AETFAT /UNSO vegetation map of Africa. UNESCO, Natural Resour. Res. 20: $1-356$

[44] WMO, (1988): Analyzing long time series of hydrological data with respect to climate Variability and change, WCAP-3, WMO/TD 224

[45] WMO, (2000) Detecting trends and other changes in hydrological data/ WCDMP 45, WMO /TD 1013.

[46] Thornthwaite, C. W. (1948): “An Approach towards a Rational Classification of climate" Geophysical review, 38, 55-94

[47] Rosenzweig, C., J. Phillips, R. Goldberg, J. Carroll, and T. Hodges, 1996: Potential impacts of climate change on citrus and potato production in the US. Agr. Systems, 52, 455-479, doi: 10.1016 /0308-521X (95)00059-E.

http://www.ipcc.ch/ipccreports/tar/wg2/index.php?idp=563

[48] Rosenthal, Donald H and Howard K. Gruenspecht 1995 “Effects of global warming on energy use for space heating and cooling in the United States", Energy Journal, Volume 16 Issue 2, pp. 77-96.

[49] Mearns, L.O., C. Rosenzweig, and R. Goldberg, 1992: Effect of changes in interannual climatic variability on CERES-Wheat yields: sensitivity and $2 \times \mathrm{CO} 2$ general circulation model studies. Agric. For. Meteorol., 62, 159-189. 
[50] Mearns, L. O., C. Rosenzweig, and R. Goldberg, 1996: The effect of changes in daily and interannual climatic variability on CERES wheat: a sensitivity study. Clim. Change, 32, 257-292.

[51] Yue S. Hashino, M. (2003): Long term trends of annual and monthly precipitation in Japan. Journal of American Water Resources Association, Volume 39 Issue 3 Page 587596, June 2003. 